\title{
İlköğretim Matematik Öğretmeni Adaylarının Matematiği Öğretme Bilgilerinin Gelişimi ${ }^{1}$
}

\section{Mesut Bütün²}

Type/Tür:

Research/Araştırma

Received/Geliş Tarihi: December

7/ 7 Aralık 2018

Accepted/Kabul Tarihi:

February 9/ 9 Şubat 2019

Page numbers/Sayfa No: 300-322

Corresponding

Author/Iletişimden Sorumlu

Yazar: butunmath@gmail.com

\section{$\checkmark$ iThenticate $^{\circ}$}

This paper was checked for plagiarism using iThenticate during the preview process and before publication. / Bu çalışma ön inceleme sürecinde ve yayımlanmadan önce iThenticate yazılımı ile taranmıştır.

Copyright $(\subset) 2019$ by Cumhuriyet University, Faculty of Education. All rights reserved.

\section{Adnan Baki ${ }^{3}$}

\section{Öz}

Öğrencilerin kavramsal bilgilerini zenginleştirmek için öğretmenlerin matematiği öğretme bilgilerinin kural ve işlem yollarını öğrenciye aktarmanın ötesinde daha nitelikli olması gerekir. Matematiği öğretme bilgisinin temelleri lisans eğitimi sürecinde atıldığı için, bu bilginin süreç içerisindeki gelişiminin incelenmesi önem arz etmektedir. Bu çalışmanın amacı, ilköğretim matematik öğretmeni adaylarının matematiği öğretme bilgilerinin gelişimini incelemektir. Araştırmada betimsel araştırma yöntemlerinden boylamasına gelişimsel araştırma yöntemi kullanılmıştır. Araştırmanın katılımcılarını, Karadeniz bölgesinde bir üniversitenin eğitim fakültesi ilköğretim matematik öğretmenliği bölümünde öğrenim gören 3. sınıftaki 35 öğretmen adayı oluşturmaktadır. Çalışmanın verileri, bir öğretme senaryosu kullanılarak toplanmıştır. Doğal sayılarda çarpma işleminin ele alındığı bu senaryo açık uçlu sorularla desteklenerek adaylara yazılı olarak yöneltilmiş ve yorumlamaları istenmiştir. Öğretme senaryosu 3. sınıfın güz dönemi başında, güz dönemi sonunda ve bahar dönemi sonunda olmak üzere toplam üç defa adaylara uygulanmıştır. Veriler, senaryoya ilişkin oluşturulan üç matematik öğretme bilgisi seviyesi yardımıyla betimsel olarak analiz edilmiş, böylece adayların hem süreç boyunca hem de dönemsel gelişimleri ortaya çıkarılmaya çalışılmıştır. Elde edilen sonuçlar, öğretmen adaylarının matematiği öğretme bilgilerinin niteliklerini genellikle birinci seviyeden ikinci seviyeye doğru geliştirdiklerini, bunun yanında üçüncü seviyeye doğru gelişimin yeterince gerçekleşmediğini göstermektedir.

Anahtar Kelimeler: Matematiği öğretme bilgisi, çarpma işlemi, ilköğretim matematik, öğretmen adayları, öğretmen gelişimi.

\section{Suggested APA Citation/Önerilen APA Atıf Biçimi:}

Bütün, M., ve Baki, A. (2019). İlköğretim matematik öğretmeni adaylarının matematiği öğretme bilgilerinin gelişimi. Cumhuriyet International Journal of Education, 8(1), 300-322. http:/ /dx.doi.org/10.30703/cije.493676

\footnotetext{
${ }^{1} \mathrm{Bu}$ çalışma birinci yazarın "İlköğretim Matematik Öğretmeni Adaylarının Uygulanan Zenginleştirilmiş Program Sürecinde Matematiği Öğretme Bilgilerinin Gelişimi” adlı doktora tezinden üretilmiştir.

2 Dr. Öğr. Üyesi, Sivas Cumhuriyet Üniversitesi, Eğitim Fakültesi, Matematik Eğitimi, Sivas/Türkiye Asst. Prof. Dr., Sivas Cumhuriyet University, Faculty of Education, Mathematics Education, Sivas/Turkey e-mail: butunmath@gmail.com ORCID ID: https:/ / orcid.org/0000-0001-7652-3674

3 Prof. Dr., Trabzon Üniversitesi, Eğitim Fakültesi, Matematik Eğitimi, Trabzon/Türkiye Prof. Dr., Trabzon University, Faculty of Education, Mathematics Education Trabzon/Turkey e-mail: adnanbaki@gmail.com ORCID ID: https:/ / orcid.org/0000-0002-1331-053X
} 


\title{
Development of Elementary Pre-service Mathematics Teachers' Pedagogical Content Knowledge
}

\begin{abstract}
In order to enrich students' conceptual knowledge, teachers' pedagogical content knowledge should be more qualified rather than transferring rules and process to students. Since the fundamentals of pedagogical content knowledge are formed during the undergraduate education process, it is important to examine the development of this knowledge in the process. The aim of this study was to examine the development of elementary pre-service mathematics teachers' pedagogical content knowledge. In this research, longitudinal developmental research method was used. The research group consisted of 35 elementary mathematics teacher candidates in the $3^{\text {rd }}$ grade at a public university in the Black Sea Region. The data of the study were collected using a teaching scenario. This scenario, which deals with the multiplication of natural numbers, was given in written form and was supported with open-ended questions and pre-service teachers were asked to interpret it. The teaching scenario was applied three times at the beginning of the fall semester of the 3rd year, at the end of the fall semester and at the end of the spring semester. The data were analyzed descriptively using the three levels of pedagogical content knowledge that were formed for the scenario. Thus, the preservice teachers' developments were examined both during the process and periodic semesters. The results showed that the quality of pre-service teachers' pedagogical content knowledge developed from the first level to the second level, but the development towards the third level was not enough.
\end{abstract}

Keywords: Pedagogical content knowledge, Multiplication, elementary mathematics, pre-service teachers, teacher development.

\section{Giriş}

Geçmişten günümüze öğretmen eğitimi araştırmalarının temel sorunlarından biri, öğretmenlik bilgi ve becerilerinin lisans eğitimi sürecinde öğretmen adaylarına nasıl ve hangi kapsamda kazandırılabileceğidir. Bu sorun, 80'li yılların ortalarından itibaren, yani alanı öğretme bilgisi (pedagogical content knowledge) ile ilgili kuramsal çerçevenin Shulman $(1986,1987)$ tarafından ortaya atılmasıyla daha fazla önem kazanmıştır. Çünkü bu yeni çerçevede öğretmen bilgisi, o zamana kadar genellikle birbirinden bağımsız olarak değerlendirilen konu alanı ve pedagoji bilgisinden ibaret sayılmamış, etkili öğretim için öğretmenlik mesleğine özgü başka tür bilgi ve becerilerin de gerekliliği ortaya konulmuştur. Öğretimde konu alanı bilgisini öğrencilerin anlamasına yardımcı olacak şekilde kullanabilme, konu ve kavramlarla ilgili öğrencilerin önbilgi, zorluk ve yanılgılarını bilme ve bu bilgiyi öğretim yöntemlerine yansıtabilme, çeşitli öğretimsel açıklama ve gösterim şekillerinin üstün ve eksik yanlarını bilme gibi öğretmen yeterlikleri ön plana çıkmıştır. Böylece mevcut lisans programlarının tekrar gözden geçirilmesi ve yenilenmesi gerekmiştir (Fenemma ve Franke, 1992; Graeber ve Tirosh, 2008). Ülkemizde de YÖK-Dünya Bankası işbirliğinde gerçekleştirilen fakülte programlarının yeniden düzenlenmesi (Yüksek Öğretim Kurumu [YÖK], 1998) ve yakın geçmişteki fakülte programlarını yenilme çalışmaları (YÖK, 2006, 2007) bu kapsamda değerlendirilebilir. Bilindiği gibi yeni programların geliştirilmesinde ve uygulanmasında eski programların çıktılarının değerlendirilmesi önem arz etmektedir. Hâlihazırda uygulamaları devam eden lisans eğitimi programlarının ve bu programlardaki derslerin öğretmen adaylarının alanı 
öğretme bilgilerinin nitelikleri üzerindeki etkisinin belirlenmesi, 2018'de geliştirilen yeni programın (YÖK, 2018) uygulamalarına da katkıda bulunacaktır.

Ponte ve Chapman (2008), matematik öğretmeni adaylarıyla gerçekleştirilen çalışmaları inceledikleri sentez niteliğindeki araştırmalarında; öğretmen adaylarının okul matematiği kapsamındaki çeşitli konu ve kavramlarda alanı öğretme bilgilerinin yeterince derin olmadığını, lisans eğitimleri sürecinde bu bilgilerini zenginleştirmeleri için farklı ders tasarımlarının geliştirilip uygulanması gerektiğini vurgulamışlardır. Ayrıca bu araştırmacılar, alanı öğretme bilgi yapılarının geliştirilmesinde etkili ders tasarımlarının ya da öğretim programlarının özelliklerinin daha iyi anlaşılıp belirlenebilmesine yönelik, adayların bilgi yapılarının lisans eğitimleri sürecinde belirli zaman aralıkları halinde ve sürecin sonunda incelenmesini önermektedirler. $\mathrm{Bu}$ çalışmada, İlköğretim Matematik Öğretmenliği Programı'ndaki Özel Öğretim Yöntemleri I-II derslerini alan öğretmen adaylarının matematiği öğretme bilgilerinin gelişimi incelenmiştir. $\mathrm{Bu}$ inceleme, ilköğretim okul matematiğinin temel konularından biri olan doğal sayılarla çarpma işlemi özelinde gerçekleştirilmiştir.

Doğal sayılarla çarpma işlemi, kural odaklı öğretimin yaygın olduğu konulardan biridir. Kural odaklı öğretimde, işlemin sonucu bulunurken uygulanan geleneksel algoritma çoğu zaman kavramsal arka planı gölgede bıraktığı için öğrenciler konuyu derinlemesine anlamada zorluk yaşarlar. Çarpma işlemini derinlemesine anlama; toplama işlemini, dağılma ve birleşme özelliğini, basamak değerini ve sıfır kavramını anlamayla doğrudan ilişkilidir (Bütün, 2005; Lampert, 1986). Ma (1999) Amerika ve Çin'deki matematik öğretmenlerinin üç basamaklı iki sayının çarpımıyla ilgili yaptıkları açıklamaları incelediği çalışmasında, kural odaklı öğretim stratejilerinin öğrencilerin işlemin sonucunu bulmalarını kolaylaştırabileceğini fakat kavramsal anlamalarına yeterince yardımcı olmayacağını belirtmiştir. Ball (1988) ise matematik öğretmeni adayları ile yürüttüğü çalışmada, adayların çarpma işlemi ile ilgili matematiği öğretme bilgilerinin niteliğinin kuralı/işlem yolunu "anlatma" ve "gösterme" yaklaşımının ötesine geçemediğini ortaya koymuştur. Ülkemizde matematik öğretmeni adaylarının farklı konu ve kavramlarda alanı öğretme bilgilerinin niteliklerini inceleyen çok sayıda araştırma yapılmıştır (Gökkurt vd., 2015; Türnüklü, 2005; Yeşildere ve Akkoç, 2010). Bu çalışmaların birçoğu durum tespiti niteliğinde olup, söz konusu bilginin lisans eğitimi sürecindeki gelişimini tam olarak yansıtmamaktadır. Matematiği öğretme bilgisi ile ilgili kuramsal çerçeve, bu bilginin şekillenmesinin uzun zaman aldığını ve adayların gelişiminin lisans eğitimi sürecinde boylamasına uzun süreli takip edilmesini önermektedir (Ponte ve Chapman, 2008).

\section{Kuramsal Çerçeve}

Öğretmen bilgisinin bir öğesi olan alanı öğretme bilgisi, kavram ve terim olarak alan yazında ilk defa Shulman'ın $(1986,1987)$ çalışmalarında kullanılmıştır. Shulman (1986), öğretmene özgü bu bilgi türünün, öğretmenlerin konu alanı bilgilerini öğretimsel amaçlar doğrultusunda şekillendirmeleri ile oluştuğunu belirtmiştir. Shulman, alanı öğretme bilgisini, öğretmeni konunun uzmanından ayıran bir bilgi olarak tanımlamıştır. Bu bakış açısına göre konuyu iyi bilmek o konuyu iyi öğretebilmek için yeterli değildir. Öğretmenin bir konuyu en uygun örnekler, temsiller, açıklamalar ve benzetmeler kullanarak başkalarının anlamasına yardımcı 
olabilmesi, konunun öğrenilmesini nelerin zorlaştıracağını ya da kolaylaştıracağını bilmesi gerekir. Baki (2010), alanı öğretme bilgisini “alan bilgisinden daha öteye giden ve derinleşen bir bilgi" olarak tanımlamıştır.

Alanı öğretme bilgisinin yukarıda ifade edilen bileşenlerini bir öğretme faaliyeti içerisinde etkili olarak kullanabilme bu bilginin niteliğini ortaya çıkarmaktadır. Örneğin, üç basamaklı iki sayının çarpımını öğretirken "basamak kaydırma kuralını" sözel olarak ifade eden ve bu durumu bir merdivene benzeterek açıklayan öğretmen ile basamak tabloları kullanarak kuralın gerekçesini anlatan öğretmenin öğretme bilgilerinin niteliği farklılaşmaktadır. Öğrencinin anlamasını sağlama yönünde ikinci yaklaşımın kullanılması muhtemelen daha etkili olacaktır. Diğer yandan başka bir öğretmen, öğrencilerin basamak tabloları üzerinde birlikte çalışmalarını isteyerek kuralın gerekçesine kendilerinin ulaşmasını sağlayabilir. Bu öğrenme ortamını oluşturan öğretmenin öğretme bilgisinin niteliği ise diğer iki yaklaşımı kullanan öğretmene göre daha üst düzey olacaktır. Sugiyama (2008), alanı öğretme bilgisinin niteliklerini resmeden üç matematik öğretme düzeyi tanımlamıştır (Takahashi, 2010). Birinci düzeyde işlem yollarını ve formülleri nasıl uygulayacağını bilen ve bunları öğrenciye söylemle aktaran rolde bir öğretmen vardır. Bu düzeydeki öğretim için alanı öğretme bilgisine ihtiyaç duyulmayacağı, yalnızca işlemsel bilginin yeterli olacağı belirtilmektedir (Takahashi, 2010). İkinci düzeyde ise öğretmenin işlem yollarının ve formüllerin arkasındaki matematiksel anlamı öğrencilerine açıklayarak öğretmeye çalışması söz konusudur. Bu nitelikte bir öğretimin gerçekleştirilmesi için öğretmenin belli bir düzeyde alanı öğretme bilgisinin olması gerekmektedir. Üçüncü düzeyde ise öğretmen öğrencilerin matematiksel bilgiyi oluşturmalarına veya keşfetmelerine yardımcı olur. Bu düzeyde, öğrenciler öğrenme süreçlerine aktif olarak katılır, öğretmen öğrencilerin matematiksel anlamasını ve düşünmesini kolaylaştırır ve teşvik eder. Bu düzeyler, Ernest'in (1989) öğretmenin öğretici, açıklayıcı ve kolaylaştırıcı rolleri çerçevesinde yapılandırdığı matematik öğretme modelindeki düzeylerle örtüşmektedir. Yine Thompson'un (1991) öğretmen gelişimi ile ilgili çalışmasında oluşturduğu üç seviye de buradaki sınıflandırmayı yansıtmaktadır. Ernest'in (1989) öğretmenin sınıf içerisindeki rollerine bağlı olarak tanımladığı düzeyler üç farklı öğretme modelini yansıtmaktadır. Öğretici rolündeki bir öğretmenin nihai amacı, doğru işlem yollarını uygulamaya yönelik becerilerde öğrencilerin ustalaşmasını sağlamaktır. Bu öğretmen, öğretimi gerçekleştirirken işlem yollarını ve kuralları öğrencilerine doğrudan aktarmaktadır. Öğretmenin açıklayıcı olarak görüldüğü modelde ise, öğretimin amacı matematiksel bilgide öğrencilerin kavramsal anlayışa sahip olmalarıdır. Öğretmen, öğrencilerine matematiksel kavram, formül ve işlemleri doğrudan açıklama yoluyla en iyi şekilde kavratmaya çalışmaktadır. Diğer yandan, kolaylaştırıcı bir öğretmenin öğretimde nihai amacı ise problem çözmedir. Öğretmen, öğrencilerinin matematiksel düşünmelerine firsat verecek görev ve sorular oluşturarak öğrenme sürecine öğrencilerini aktif olarak dâhil etmeye çalışır, onların anlamasını kolaylaştırır. Matematikte farklı konu ve kavramların öğretimine uyarlanabilecek bu düzeyler, matematik öğretmeni adaylarının mesleki gelişimlerinin incelenmesinde bir kavramsal altyapı olarak kullanılarak, söz konusu gelişimin seyri ve niteliği net bir biçimde ortaya çıkarılabilir.

Bu çalışmada, bir grup ilköğretim matematik öğretmeni adayının matematiği öğretme bilgilerindeki gelişimin incelenmesi amaçlanmıştır. Ernest'in (1989) 
tanımladığı düzeylere bağlı olarak yapılan bu inceleme, doğal sayılarla çarpma işlemi özelinde, Özel Öğretim Yöntemleri I-II dersleri öncesinde ve sonrasında gerçekleştirilmiştir.

\section{Yöntem}

$\mathrm{Bu}$ araştırmada betimsel araştırma yöntemlerinden boylamasına gelişimsel araştırma yöntemi kullanılmıştır (Çepni, 2012). Boylamasına yürütülen çalışmalarda odaklanılan temel nokta, araştırılan bir olgu, olay ve hususun süreç içerisinde belirli zaman dilimlerinde nasıl değiştiğine ve geliştiğine vurgu yapılmasıdır. Bu araştırmada, ilköğretim matematik öğretmenliği programında 3. sinıftaki adaylarla boylamasına çalışılarak, alanı öğretme bilgi yapılarının süreçte nasıl geliştiği belirlenmeye çalışılmıştır.

\section{Çalışma Grubu}

Araştırmanın katılımcıları, olasılık temelli olmayan örnekleme yöntemlerinden uygun örnekleme yöntemiyle belirlenmiştir. Bu yöntemde katılımcılar, ulaşılması kolay, araştırma için uygun ve gönüllü bireylerden seçilmektedir (Koç Başaran, 2017). Araştırmanın katılımcılarını, Karadeniz bölgesinde bir üniversitenin eğitim fakültesi ilköğretim matematik öğretmenliği bölümünde öğrenim gören 3. sınıftaki 35 öğretmen adayı oluşturmaktadır. Öğretmen adaylarının 3. sınıftan seçilmesinin nedeni, Özel Öğretim Yöntemleri I-II derslerini almadan önce ve aldıktan sonra matematiği öğretme bilgilerinin niteliklerinin karşılaştırılmak istenmesidir. Özel Öğretim Yöntemleri I dersinde fakültede uygulanan program, "Sınıfta Öğrenme Kuramları", "Matematiksel Öğrenme" ve "Öğretme Etkinlikleri" başlıkları altında üç ana bölümden oluşmaktadır. "Sınıfta Öğrenme Kuramları" bölümünde içerik olarak, öğrenme kuramları ve farklı öğretim yöntemlerinin matematik öğretiminde kullanılması konuları ele alınmaktadır. "Matematiksel Öğrenme” başlığı altında ise, işlemsel ve kavramsal öğrenme, kavram yanılgılarının teşhis edilmesi ve geometriyi anlama düzeyleri yer almaktadır. Diğer yandan, "Öğretme Etkinlikleri” kapsamında ele alınan konular ise; sayıların öğretimi, kesirler ve ondalık sayılar, kural öğretimi, matris öğretimi, küme kavramı ve öğretimi, cebir öğretimi, fonksiyon kavramı ve öğretimi, logaritma fonksiyonu, analiz kavramları şeklindedir. Bu içeriklere ek olarak, bu çalışma kapsamında geliştirilen bir takım etkinliklerle de Özel Öğretim Yöntemleri I dersinin içeriği zenginleştirilmiştir. Bu ekinlikler; problem çözme etkinliği, buluş yoluyla öğrenme etkinliği, problem oluşturma çalışması/yarışması ve kavram haritası oluşturma çalışmasıdır. Özel Öğretim Yöntemleri II dersinde ise, fakültede uygulanan programda, ilköğretim matematik öğretim programındaki kazanımlara yönelik ders planları oluşturma, sunma ve değerlendirme etkinlikleri yapılmıştır. Bu etkinliklere ilave olarak, bu çalışma kapsamında mikro-öğretim etkinlikleri ve proje taslağ oluşturma çalışmaları ile dersin içeriği zenginleştirilmiştir.

\section{Veri Toplama Araçları}

Çalışmada öğretmen adaylarının matematiği öğretme bilgilerinin gelişimini incelemek için, açık uçlu sorularla desteklenmiş bir öğretme senaryosu hazırlanmıştır. Öğretme senaryoları, çoğunlukla öğretmenlerin gündelik işlerinden kırpılmış kritik kesitlerden oluşturulmaktadır. Bu kesitler, gerçek sınıflardan doğrudan gözlemler yardımıyla ya da çeşitli araştırma bulgularından hareketle oluşturulabileceği gibi, 
öğrencilerin öğrenme zorlukları ve kavram yanılgıları ile ilgili alan yazın kullanılarak veya öğretim programının ve ders ile ilgili materyallerin incelenmesi sonucu değişik yöntemlerle oluşturulabilmektedir (Bütün, 2011). Doğal sayılarda çarpma işleminin ele alındığı bu çalışmadaki öğretme senaryosu, adaylara yazılı olarak yöneltilmiş ve yorumlamaları istenmiştir. Senaryo, 3. sınıfın güz dönemi başında, güz dönemi sonunda ve bahar dönemi sonunda olmak üzere toplam üç defa adaylara uygulanmıştır.

$\mathrm{Bu}$ çalışmada veri toplama aracı olarak kullanılan, üç basamaklı iki sayının çarpımı konusunun işlendiği senaryo, öğretmen/öğretmen adaylarının alan ve alanı öğretme bilgilerinin incelendiği birçok araştırmada kullanılmıştır (Ball, 1988; Bütün, 2005; Leung ve Park, 2002; Ma, 1999). Senaryoda öğretmen adaylarından, öğrencilerin üç basamaklı iki sayının çarpımını hesaplarken "basamak kaydırma kuralını unutarak" yaptıkları hatayı yorumlamaları ve bu hatanın üstesinden gelmek için bir öğretme planı oluşturmaları istenmiştir. Bu öğretme planında; hatanın üstesinden gelmeye yönelik hangi öğretim yöntem ve yaklaşımlarının kullanıldı̆̆ı, hatayı "düzeltme" şekilleri, tasarlanan farazi öğrenme-öğretme ortaminda öğrenci/öğretmenin rolleri gibi boyutlarda matematiği öğretme bilgilerinin nitelikleri incelenmiştir. Senaryoyu, 1 . uygulamada 35,2 . uygulamada 34,3 . uygulamada ise 33 aday cevaplamıştır.

\section{Verilerin Analizi}

Araştırmanın verileri, öğretme senaryosuna ilişkin oluşturulan üç matematik öğretme bilgisi seviyesi yardımıyla betimsel olarak analiz edilmiş, böylece adayların hem süreç boyunca hem de dönemsel gelişimleri ortaya çıkarılmaya çalışılmıştır. Bu seviyeler, Ernest'in (1989) öğretmenin öğretici, açıklayıcı ve kolaylaştırıcı rolleri çerçevesinde yapılandırdığı matematik öğretme modeli seviyeleri temel alınarak oluşturulmuştur. Çalışmada kullanılan senaryoya özgü öğretme bilgisi seviyelerinin göstergeleri, bulguların aktarıldığı ilgili bölümlerin başlangıç kısımlarında sunulmuştur.

Senaryoya yönelik yapılan açıklamalar analiz edilirken, ilk aşamada yukarıda tanıtılan öğretme bilgisi seviyeleri kullanılarak üç farklı uygulamadaki cevaplar kodlanmıştır. Yapılan analizin güvenirliğini sağlamak için bu işlem birkaç kez tekrar etmiş ve seviyelerin göstergeleri çalışma dışındaki başka bir matematik eğitimcisine de sunularak, cevapları bu seviyelere bağlı olarak sınıflandırması istenmiştir. Yazılı cevapların seviyelere bağlı olarak sınıflandırılmasında zorluk yaşandığı ve uzlaşmanın sağlanamadığı durumlarda, ilgili adaylarla verdikleri cevaplar üzerinde informal görüşmeler yapılmıştır. Bu görüşmelerde, adayların matematiği öğretme bilgilerinin hangi düzeyde sınıflandırılacağını belirlemeye yönelik sorular sorulmuştur. Örneğin, yazılı açıklamalarının içeriğine bağlı olarak adaylara "verdiğiniz cevapta bunu mu (yazılı cevabını belli bir seviyeyle ilişkilendirerek) demek istediniz?" şeklinde soru yöneltilmiştir. Adayların matematiği öğretme bilgilerinin farklı uygulamalarda gelişip gelişmediğini belirlemek için seviyelere bağlı olarak yüzde dağılım çizgi grafiği oluşturulmuştur. Daha sonraki aşamada ise, seviyelerin kendi içerisindeki farklılıklara odaklanılmış ve bu farklılıkları en iyi temsil edebilecek yazılı cevaplar seçilmiştir. Bu adayların cevapları bulguların sunumunda doğrudan aktarılmış ve betimsel olarak yorumlanmıştır. Diğer yandan matematiği öğretme bilgisindeki bireysel gelişimin resmedilmesine yönelik, bazı adayların farklı uygulamalardaki cevaplarından da kesitler sunulmuştur. Böylece, çizgi grafikten 
yansıyan senaryodaki genel gelişim eğrisinin bireysel olarak resmedilmesi amaçlanmıştır.

\section{Bulgular}

Bulguların sunumunda, ilk aşamada öğretmen adaylarının senaryo için farklı zamanlarda verdikleri cevaplar, matematiği öğretme bilgisi seviyelerine göre ayrıştırılmış ve yorumlanmıştır. İkinci aşamada ise, bu seviyelere bağlı olarak adayların süreçteki gelişimlerine ilişkin elde edilen bulgular aktarılmıştır. Böylece dönemlere bağlı olarak adayların gelişiminin ortaya konulması amaçlanmıştır.

\section{Öğretmen Adaylarının Matematiği Öğretme Bilgisi Seviyeleri}

Öğretmen adaylarının farklı zamanlarda senaryo için yaptıkları açıklamalar matematiği öğretme bilgisi seviyelerine göre sınıflandırılmıştır. Aşağıda bu açıklamalardan her bir seviyeyi yansıtıcı örnek kesitler sunulmuş ve bunlara bağlı yorumlamalar yapılmıştır. A1, A2, A3... şeklinde isimlendirilen adayların ifadelerinden aktarılan kesitlerin senaryonun hangi uygulamasından alındığını belirtmek için, 1.uygulama için ' $a$ ', 2. uygulama için ' $b$ ', 3. uygulama için ' $c$ ' harfi kullanılmıştır. Örneğin A3b, A3 öğretmen adayının 2. uygulamadaki cevabını göstermektedir.

İşlem yolunu öğretme (1. Seviye). Cevapları bu seviyede sınıflandırılan öğretmen adayları, çarpma işlemindeki algoritmanın nasıl işlediğine ilişkin kuralları öğrenci/öğrencilere doğrudan anlatma eğiliminde olmuşlardır. Önerdikleri öğretim yaklaşımlarında kuralların altındaki anlama değinmemiş ve açıklamalarında öğretmene kuralları ve işlem yollarını öğretici rolü biçmişlerdir.

Diğer uygulamalara nazaran 1. uygulamada sayıları daha fazla olan bu adaylar, verdikleri cevaplarda çarpma işlemi yapma kuralının öğretmen tarafından ifade edilmesini yeterli görmüşlerdir. Örneğin A13 ve A22, öğrencinin hatasının bir basamak sola kaydırmamaktan kaynaklandığını ve bu hatayı anlama vurgu yapmadan yalnızca söylemle düzeltebileceklerini aşağıdaki gibi ifade etmişlerdir:

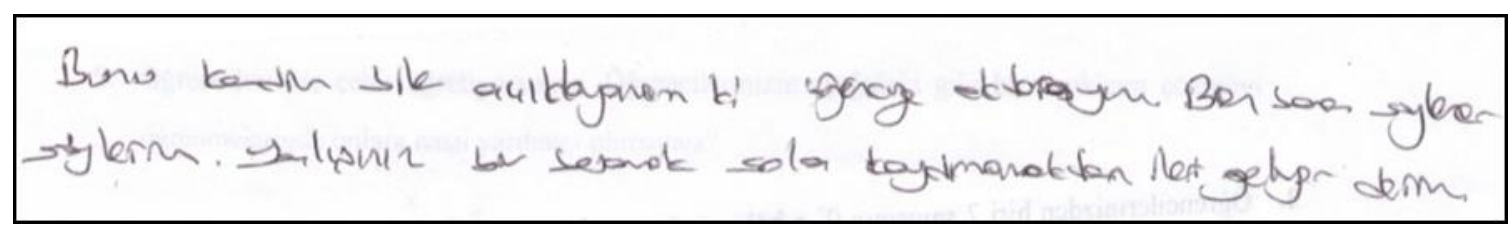

Şekil 1. A13a' nın açıklaması

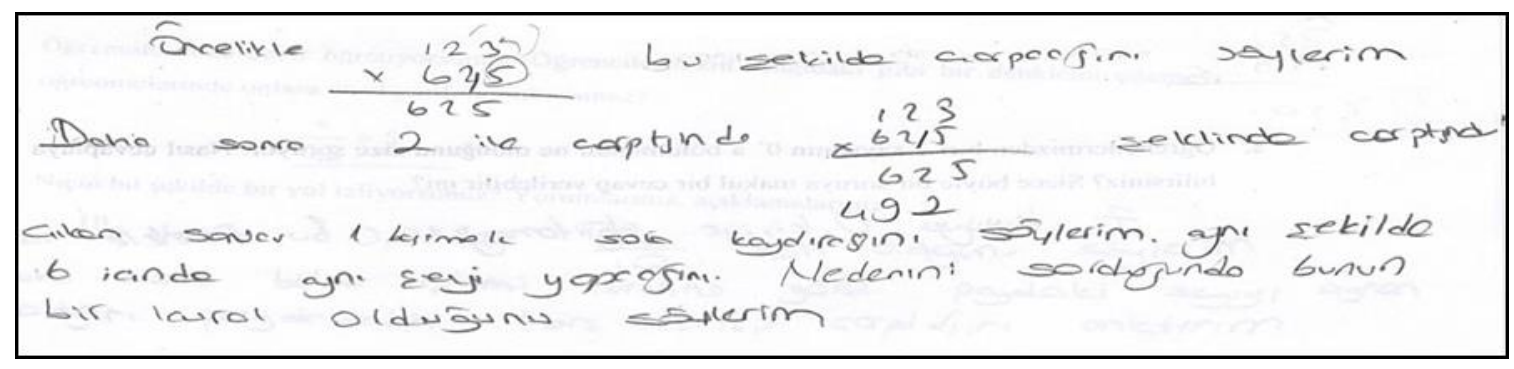

Şekil 2. A22a'nın açıklaması

Yukarıdaki ifadeler, öğretme yaklaşımlarının sayıların nasıl konumlanacağı ile ilgili işlem yolunu gösterme amaçlı açıklamaların ötesine geçemediğini 
yansıtmaktadır. Yine adayların bu yaklaşımlarında, çarpma işleminde yapılan hatayı işlemin arkasındaki anlama vurgu yapmadan doğrudan "düzeltme" eğiliminde oldukları da görülmektedir. Diğer yandan, öğretmen adaylarının yukarıdaki cevaplarının öğretmenin rolü ile ilgili anlayışlarını da belli ölçüde yansıttığı söylenebilir. Örneğin A13, kendisinin açıklamada zorluk çektiği bir konuyu öğrenciye nasıl aktarabileceğini sorguladığı ve konunun öğretimine yönelik yalnızca kendisine söyleneni söyleyebileceğini ifade ettiği yaklaşımında, öğretmenin rolüyle ilgili anlayışını yansıtmaktadır. Bu seviyede sınıflandırılan diğer adayların da benzer olarak, kullandıkları ifadelerde öğretmeni; "nedenini doğrudan söyleyen" ya da aşama aşama anlatan rolünde konumlandırdıkları ortaya çıkmıştır.

Öğretme bilgisi bu seviyede sinıflandırılan bazı adaylar ise, "merdiven yöntemi" olarak adlandırdıkları yöntemi kullanarak, aşağıda örneklenen açıklamadaki gibi yorumlar yapmışlardır:

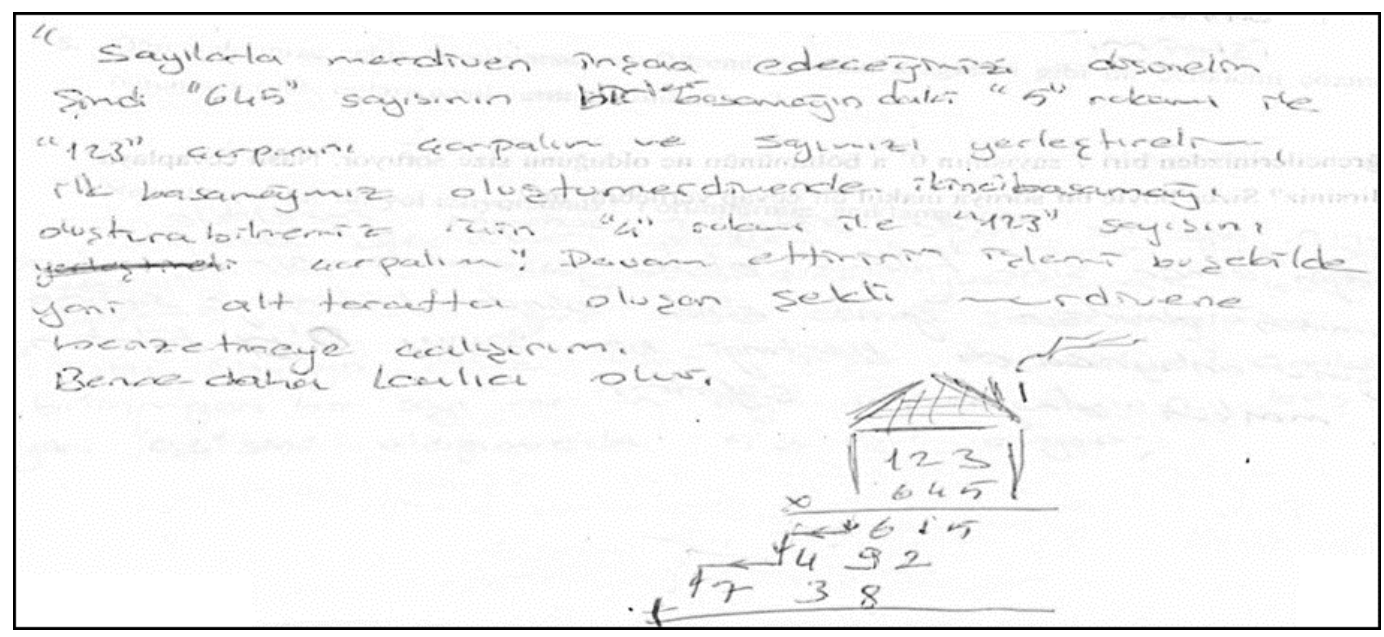

Şekil 3. A19a'nın açıklaması

Yukarıda kullanılan merdiven benzetmesi, öğrencilerin sonraki öğrenmelerinde karşılaşacakları çarpma işlemlerinde sayıların nasıl konumlandıklarını hatırlamalarına yardımcı olabilecek nitelikte bir yol olarak değerlendirilebilir. Fakat dikkat edileceği üzere bu benzetme, işlem yolunun nedeninin anlamlandırılmasında işe yaramamaktadır. Yani bir başka deyişle adayların öğretme bilgileri, kuralın ifade edilmesi yaklaşımının ötesine geçememiştir.

Anlamı açıklama (2. Seviye). Bu düzeydeki öğretmen adayları çarpma işlemindeki algoritmanın ne anlama geldiğini, niçin o şekilde işlediğini öğrenciye doğrudan gösterip anlatabileceklerini ifade etmişlerdir. Öğretim yaklaşımlarında kendi rollerini, bilginin açıklayıcısı ve otoritesi olarak konumlandıran bu adaylar, öğrencilerin yaptıkları hatanın kavramsal nedenlerinin olabileceğini değerlendirmekle birlikte, bizzat kendileri doğrusunu anlatarak fakat anlama vurgu yaparak düzeltme girişiminde bulunmuşlardır.

Senaryonun uygulandığı üç uygulamada da adayların büyük bir çoğunluğunun cevapları bu seviyede sınıflandırılmıştır. Fakat aşağıda örnekleneceği üzere, adayların bu doğrudan gösterip anlatma işini detaylandırdıkları öğretme planlarında kullandıkları yöntemlerin farklılaşabildiği ortaya çıkmıştır. Sözgelimi, bu seviyede sınıflandırılan adayların büyük bir çoğunluğu anlatma ve gösterme odaklı 
yaklaşımlarında sadece sözel ifadeleri kullanırken, diğer bazıları bu sözel ifadelerini desteklemek için basamak tablolarını kullanma, daha küçük sayılarda çarpma yapma, 10 ve 100 ile çarpma yapma, hatalı çarpma işleminin sonucunu çarpanlardan birine bölme ya da hesap makinesi ile sonucu kontrol etme gibi farklı yollarla konuyu kavratma girişiminde oldukları belirlenmiştir.

Aşağıda, senaryodaki çarpma işleminde algoritmanın anlamlandırılmasına yönelik, öğrenci/öğrencilere sadece sözel ifadeler kullanarak açıklama yapabileceğini belirten bazı adayların söylemlerinden kesitler aktarılmıştır. Örneğin, A12 çarpma işlemini öğretirken, çarpılan sayıların her bir basamağını kendi arasında çarparak kısmi çarpımların nasıl oluşturulduğunu aşağıdaki şekilde ifade etmiştir:

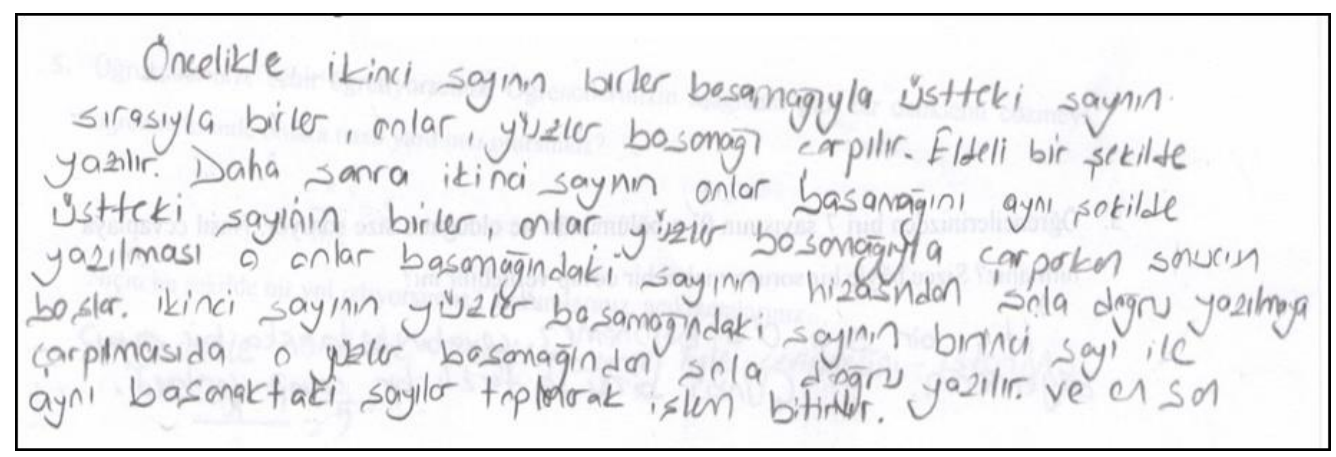

Şekil 4. A12a'nın açıklaması

A25 ise, öğrencilerin kavramsal eksikliklerine vurgu yaparak, çarpilan, çarpan ve çarpım kavramlarını öğrencilere "verdikten" sonra, işlemin nasıl gerçekleştiğini aşağıdaki şekilde açıklayabileceğini ifade etmiştir:

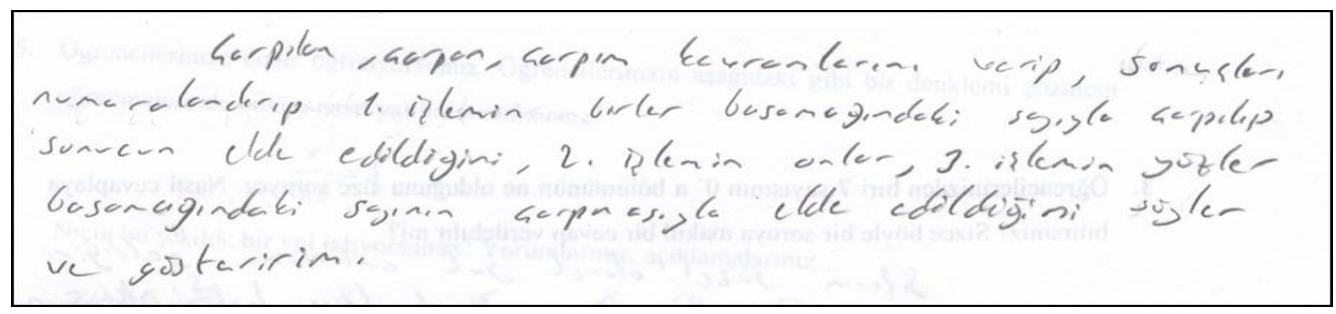

Şekil 5. A25a' nın açıklaması

Yine, A2'nin hatayı yapan öğrenciye yönelik kurguladığı öğretme planında, işlemsel basamakların nasıl gerçekleştirildiğini aşama aşama öğrenciye aktardığı görülmektedir:

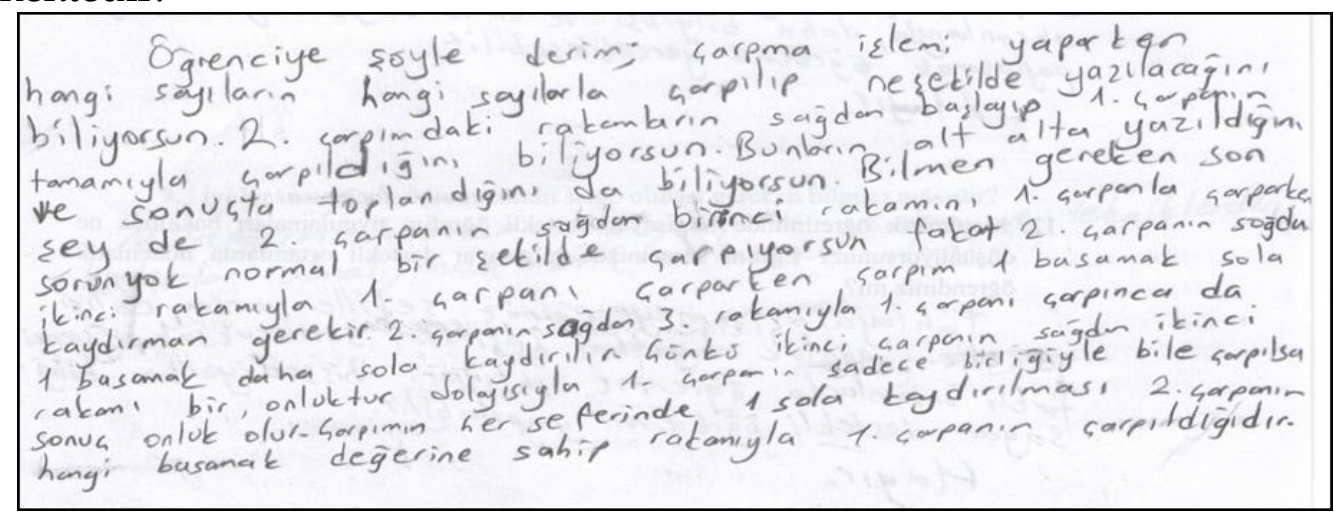

Şekil 6. A2b'nin açıklaması 
Çarpma işlemindeki algoritmanın öğrenci tarafından anlamlandırılmasına yönelik yukarıda aktarılan kesitlerde, adayların basamak değeri kavramına odaklandıkları görülmektedir. Ayrıca, bu adayların öğrencinin anlamasında ya da hatasının düzeltilmesinde, öğretmenin yalnızca sözel ifadelerinin yeterli olabileceği yönünde bir algıya sahip oldukları da söylenebilir. Yine yukarıdaki ifadelerinde adaylar, öğretmeni kavramsal bilginin dağıtıcısı ya da aktarıcısı konumunda ele alarak, öğretmenin rolüne ilişkin bakış açılarını yansıtmışlardır. İlk seviyedeki adaylardan farklı olarak burada algoritmanın öğretiminin, yalnızca "kuralı böyledir" şeklinde açıklamalarla değil, kavramsal gerekçelendirmelerle sağlanmaya çalışıldığ 1 görülmektedir.

Açıklamaları bu seviyede sınıflandırılan bazı adaylar ise, doğrudan anlatım yönteminin baskın olduğu öğretim yaklaşımlarında basamak tablolarını kullanmışlardır. Aşağıda bu öğeleri kullanan adaylardan ikisinin açıklamalarından kesitler sunulmuştur. Örneğin A19, kısmi çarpımlardaki her bir sayıyı birlikler cinsinden ifade ederek aşağıdaki tabloları oluşturmuş ve sözlü anlatımlarıyla işlemsel basamakları aşağıdaki gibi detaylandırmıştır:

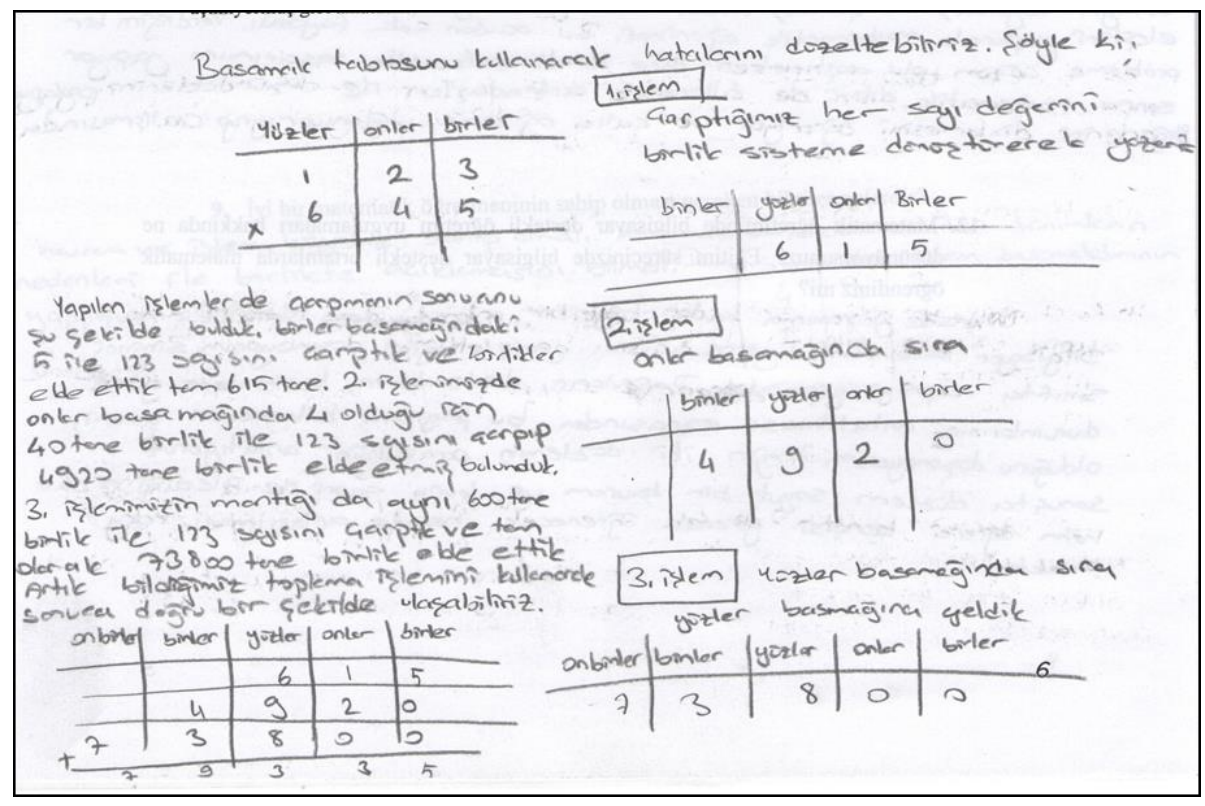

Şekil 7. A19b' nin açıklaması

A28 ise, konuyu basamak tablosu yaparak anlatabileceğini ifade ederek aşağıdaki tabloyu oluşturmuştur:

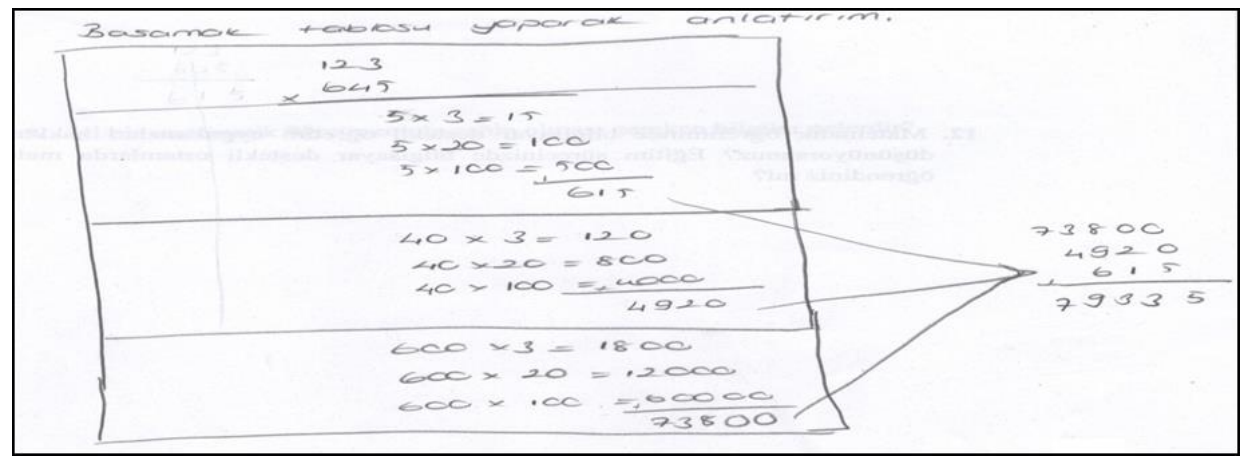

Şekil 8. A28c'nin açıklaması 
Yukarıdaki öğretim yaklaşımlarında, adayların basamak değeri kavramına doğrudan vurgu yaptıkları ve öğrencilerin hatasını "düzeltmek" için sözel ifadelerinin yanı sıra basamak tablosunu kullandıkları görülmektedir. Yine buradaki açıklamalarıyla, adayların öğrettikleri konuyla ilgili bilgilerini doğrudan öğrenciye aktarma eğiliminde oldukları da söylenebilir. Çarpma işleminde gerçekleştirilen algoritmanın ne anlama geldiğini tam olarak özümsemiş görünen bu adaylar, kendi üst düzey konu bilgilerini doğrudan anlatım yoluyla öğrencinin de kazanabileceğini düşünmektedirler.

$\mathrm{Bu}$ seviyede sınıflandırılan adaylardan bazıları, öğretim tasarımlarında senaryoda verilen çarpma işlemindeki sayılardan daha küçük sayılarla çarpma işleminin yapılması gerektiğini önermişlerdir. Basitleştirme olarak adlandırılabilecek bu yaklaşımı kullanan adaylardan A3, öğrencilerin hatasını basamak kavramını bilmiyor olmalarına bağlayarak aşağıdaki açıklamayı yapmıştır:

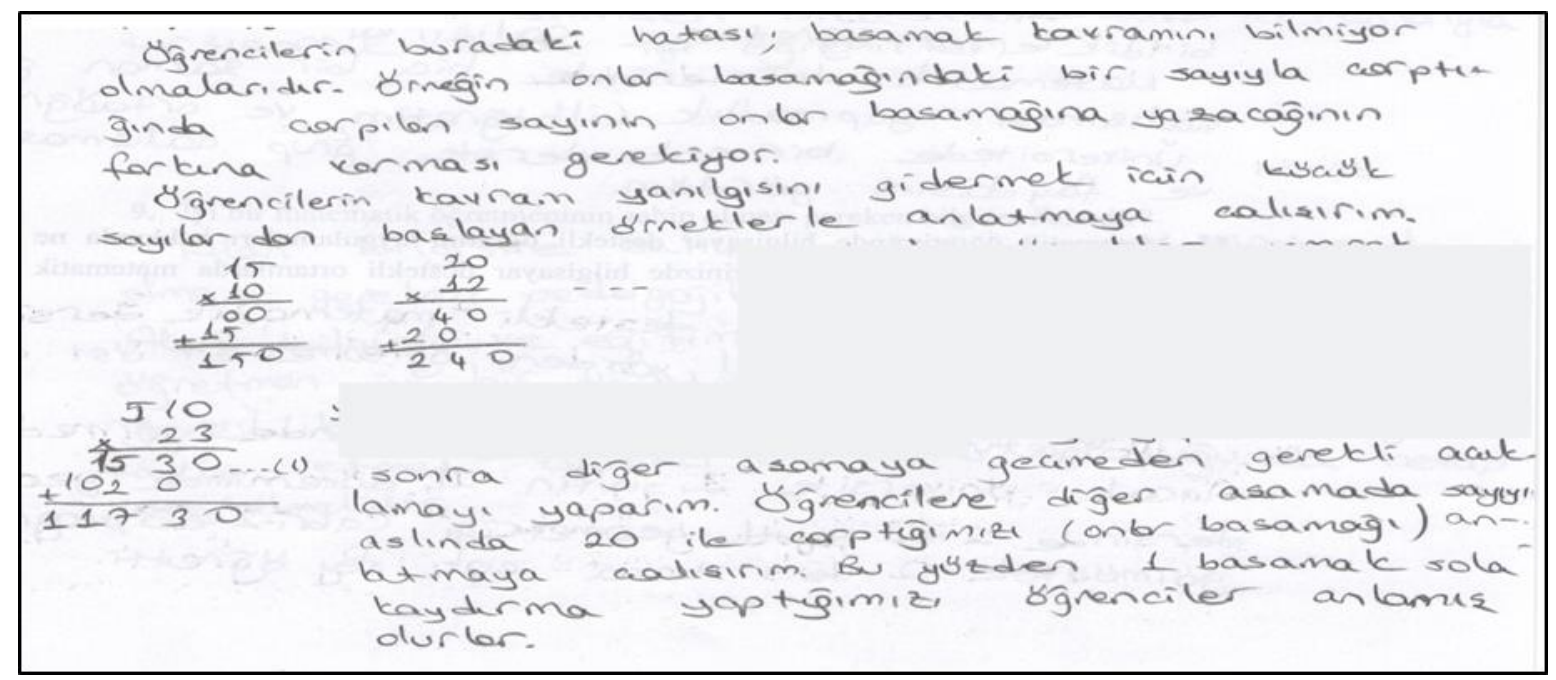

Şekil 9. A3b'nin açıklaması

Yukarıdaki açıklamanın, öğrencilerin hatasının kavramsal zorluklara bağlı olarak gerçekleştiği fikrinde olan, daha küçük sayılarda verdiği örneklerle de kavrama vurgu yapan fakat bu işi tahtada doğrudan anlatma yoluyla gerçekleştiren bir öğretmen portresini yansıttığı söylenebilir.

Yine bu seviyede sinıflandırılan adayların bazıları, 10 ve 100 ile çarpma örnekleri kullanarak algoritmayı öğrencinin anlamlandırmasında yardımcı olabileceklerini ifade etmişlerdir. Aşağıda, senaryodaki gibi hata yapan öğrenciden $123 \times 10$ çarpma işlemini yapmasını isteyebileceğini belirten bir adayın söylemlerinden bir kesit aktarılmıştır:

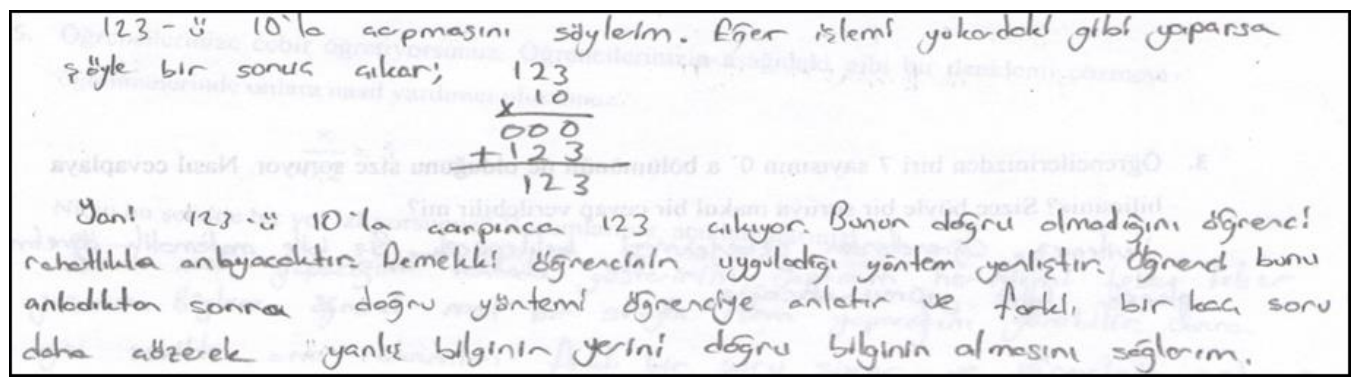

Şekil 10. A11a'nın açıklaması 
Yukarıdaki açıklamada, A11 öğrencilerin 10'un katları ile çarpmaya ilişkin ön bilgilerini harekete geçirerek bir örnek sunmuş, yaptıkları yanlışı kendilerinin görmesine fırsat vermiştir. Fakat bu örnek, öğrencilerin kavramsal anlayışlarını oluşturmada bir araç olarak ele alınmaktan ziyade, adayın doğrudan anlatımını desteklemek amacıyla kullanılmıştır. Benzer şekilde açıklama yapan adaylar, öğrenciye hatasını doğrudan söylemek yerine bu tarzda örnekler kullanmış, fakat algoritmanın nedenlerine ilişkin kavramsal anlayışların kazanılmasını yine kendi doğrudan açıklamalarıyla sağlamaya çalışmışlardır.

$\mathrm{Bu}$ seviyedeki adaylardan bir kaçı ise, öğrencilerin yaptıkları hatayı fark etmelerine yönelik, çarpma işleminin sonucunu çarpanlardan birine böldürme veya hesap makinesiyle sonucu kontrol etme yaklaşımı kullanabileceklerini ifade etmişlerdir. Aşağıda, bu yönde verilen cevapları örneklemek için A10'nun açıklamasından bir kesit sunulmuştur:

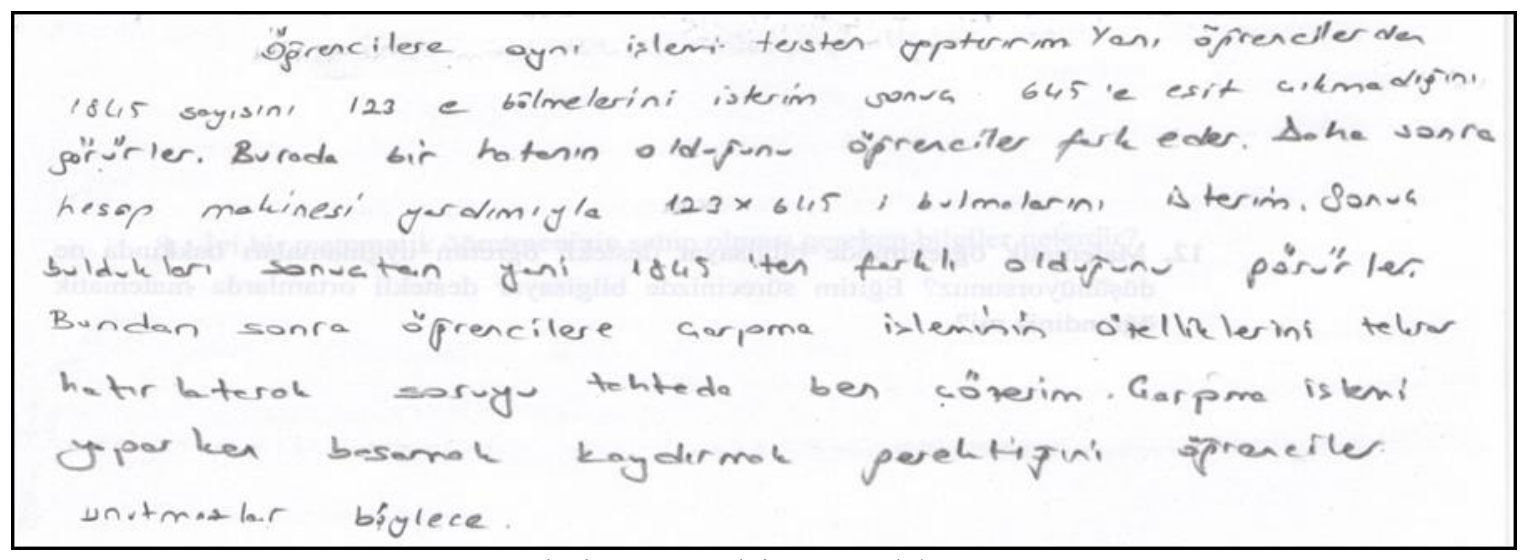

Şekil 11. A10b'nin açıklaması

Yukarıda görüldüğü gibi A10, çarpma işleminin özelliklerini hatırlatarak ve tahtada tekrar çözerek öğretebileceğini ve böylelikle öğrencilerin basamak kaydırma kuralını unutmayacağını söylemekle, kendi rolü ve öğrencinin öğrenmesi hakkındaki fikirlerini yansıtmıştır.

Sonuç itibariyle, bu seviyedeki adayların konunun öğretimine yönelik kullandıkları ya da önerdikleri yaklaşımlar, yukarıdaki kısımda da örneklendiği gibi farklılıklar gösterebilmektedir. Fakat tüm yaklaşımlarda öğretmen, konuyu doğrudan açıklayan, hatayı - doğrusunu anlatarak - "düzelten", böylelikle kavramsal bilgiyi öğrencisine aktaran bir otorite konumundadır. İşlem yolunu anlamlandırma sürecinde yer yer öğrenciye rol biçilse de, temel olarak öğretmen ön plandadır. Ayrıca öğretim tasarımlarında öğrenci-öğrenci etkileşimine neredeyse hiç değinilmemiş, daha ziyade öğretmenden öğrenciye tek yönlü bir bilgi akışının söz konusu olduğu yaklaşımlar tercih edilmiştir.

Anlamayı kolaylaştırma (3. Seviye). Bu düzeydeki öğretmen adayları öğretim yaklaşımlarında kendilerini konuyu doğrudan açıklayan olarak konumlandırmamış, öğrenciyi/öğrencileri çarpma işleminin arkasındaki anlama yönlendirebileceklerini ifade etmişlerdir. Yine adaylar, yapılan hatanın kavramsal nedenlerinin olabileceğini belirtmekle birlikte, öğrencilerin yapılan hatanın nedenleri üzerine düşünmelerine ve düzeltmelerine fırsat verecek farklı yaklaşımlar kullanmışlardır. Senaryoyu farklı zamanlarda cevaplayan çok az sayıda adayın 
ifadeleri bu üst düzey öğretme bilgisi seviyesinde sınıflandırılmıştır. Bu seviyedeki adaylar öğretme planlarında, hesap makinesi ya da sağlama yoluyla sonucu kontrol etme ve bir sayıyı 10'un katları çarpma örneğini kullanmışlardır. Fakat bu öğeleri kullanım şekilleri ve öğretimdeki vurguları 2. seviyede örneklenen durumlardan farklı yönde olmuştur.

Öğrencilerin çarpma işlemindeki hatasının nedenini doğrudan söylemek ya da hatanın kaynağının ne olduğunu anlatmak yerine, hesap makinesi ve sağlama yaklaşımı kullanılarak öğrencileri uygun anlamları kendilerinin oluşturmaları için yönlendirebileceklerini ifade eden az sayıda adayın ifadelerini örneklemek için aşağıda iki kesit sunulmuştur:

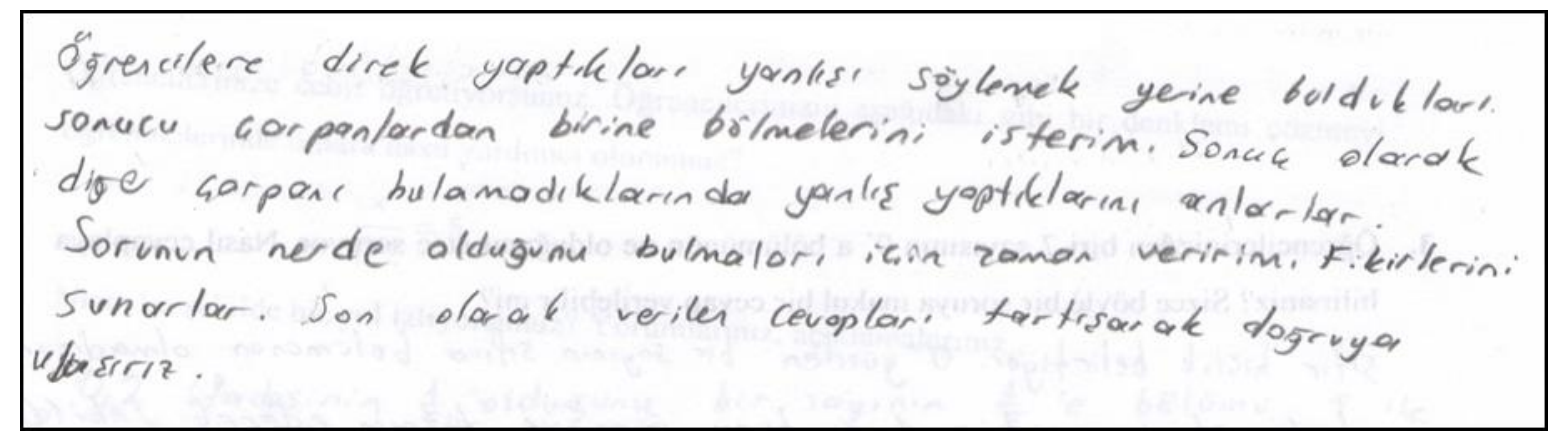

Şekil 12. A16a'nın açıklaması

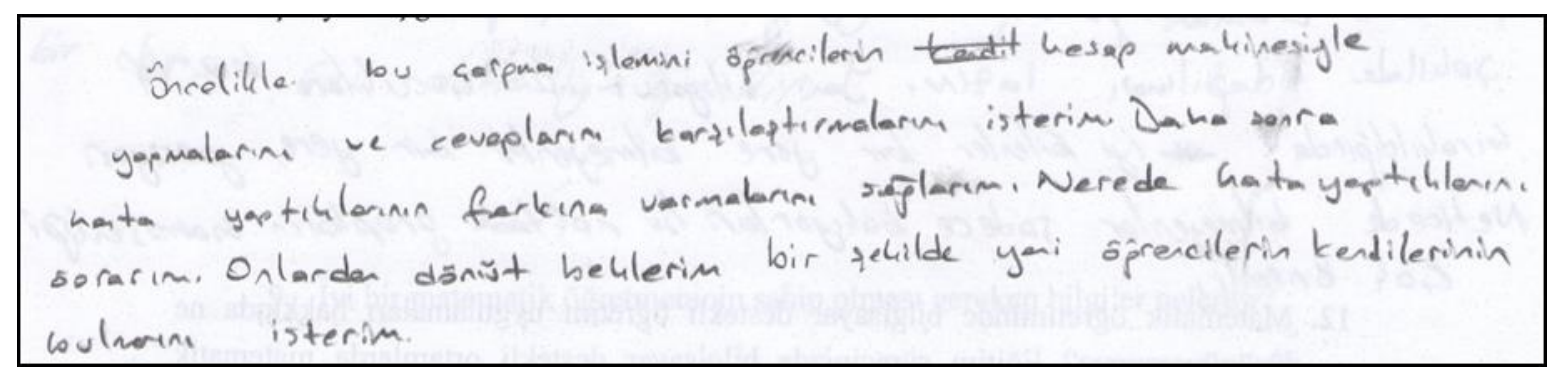

Şekil 13. A14c'nin açıklaması

Yukarıdaki ifadelere dikkat edildiğinde, öğretmenin konuyu ya da kavramı doğrudan anlatan konumda olmadığı görülmektedir. Adayların, önerdikleri farklı yaklaşımlarla öğrencilerin yaptıkları hatayı fark etmelerine ve ortaklaşa çözüm üretmelerine yönelik onları yönlendirme gayreti içerisinde oldukları söylenebilir. Ayrıca bu açıklamalarda, öğrenci-öğretmen etkileşiminin yanı sıra kısmen öğrenciöğrenci etkileşimine de vurgu yapıldı̆̆ı görülmektedir.

Senaryoda yapılan hatanın sınıfta tartışmaya açılmasını öneren ve kavramsal anlayışların oluşmasında öğrenci-öğrenci etkileşimine net bir şekilde vurgu yapan diğer bir adayın açıklamaları ise Şekil 14'de sunulmuştur. Öğretmen adayı hatanın nedenini, basamak değerinin işlemdeki rolünün kavranmamasına bağlamıştır. Şekil 14 'de verildiği üzere, aday hatanın nedenini basamak değerinin işlemdeki rolünün kavranmamasına bağlamıştır. Ayrıca bu aday hatayı doğrudan düzeltme girişiminde bulunmamış, öncelikle öğrenciyi hesap makinesi yardımıyla sonucu kontrol etmeye yönlendirebileceğini ifade etmiş ve sonrasında da hatanın kaynağına ilişkin sınıfta bir tartışma ortamı açarak doğruya birlikte ulaşılabileceğini belirtmiştir. 


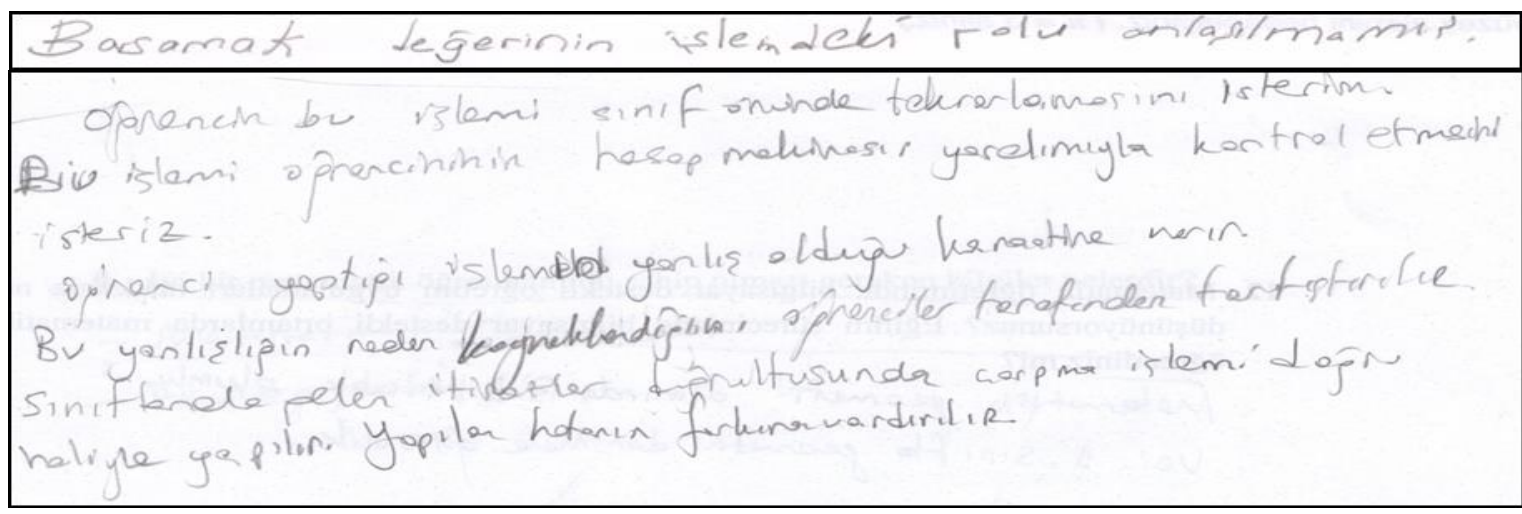

Şekil 14. A18c'nin açıklaması

Özetle, sayıları senaryonun üç uygulamasında da sayıları oldukça az olan bu seviyedeki adaylar, öğrenciyi/öğrencileri çarpma işleminin arkasındaki anlama yönlendirebileceklerini ifade etmişlerdir. Yine bu adaylar tanımladıkları öğretim yaklaşımlarında, kendilerini konuyu ya da kavramı doğrudan açıklayan olarak konumlandırmamışlardır.

\section{Öğretmen Adaylarının Matematiği Öğretme Bilgilerinin Gelişimi}

Öğretme bilgisinin seviyelere bağlı olarak ve seviyeler içerisinde nasıl farklılaştığının aktarıldığı yukarıdaki bölümden sonra, dönemsel olarak adayların gelişimlerini göstermek amacıyla aşağıda bazı öğretmen adaylarından özel örnekler verilmiş, böylelikle gelişim süreci aday bazında bireysel olarak somutlaştırılmıştır.

Örneğin, ilk iki uygulama arasında gelişim gösteren adaylardan A2'nin ilk uygulamadaki aşağıdaki cevabıyla 1. seviyede yer aldığı görülmektedir:

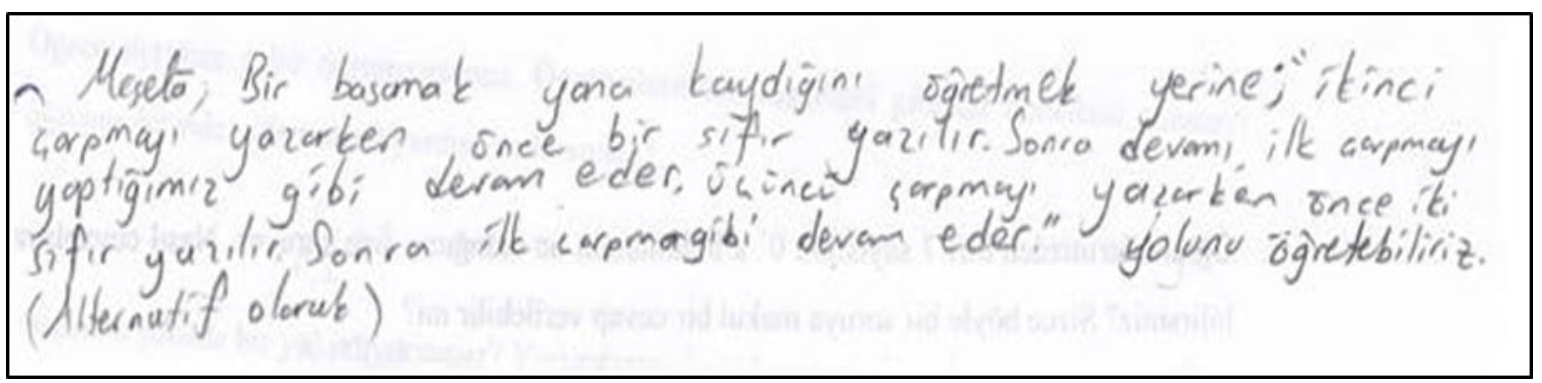

Şekil 15. A2a' nın açıklaması

Yukarıdaki adayın senaryonun 2. uygulamasında aşağıdaki açıklamasıyla 2. seviyeye yükseldiği görülmektedir: 


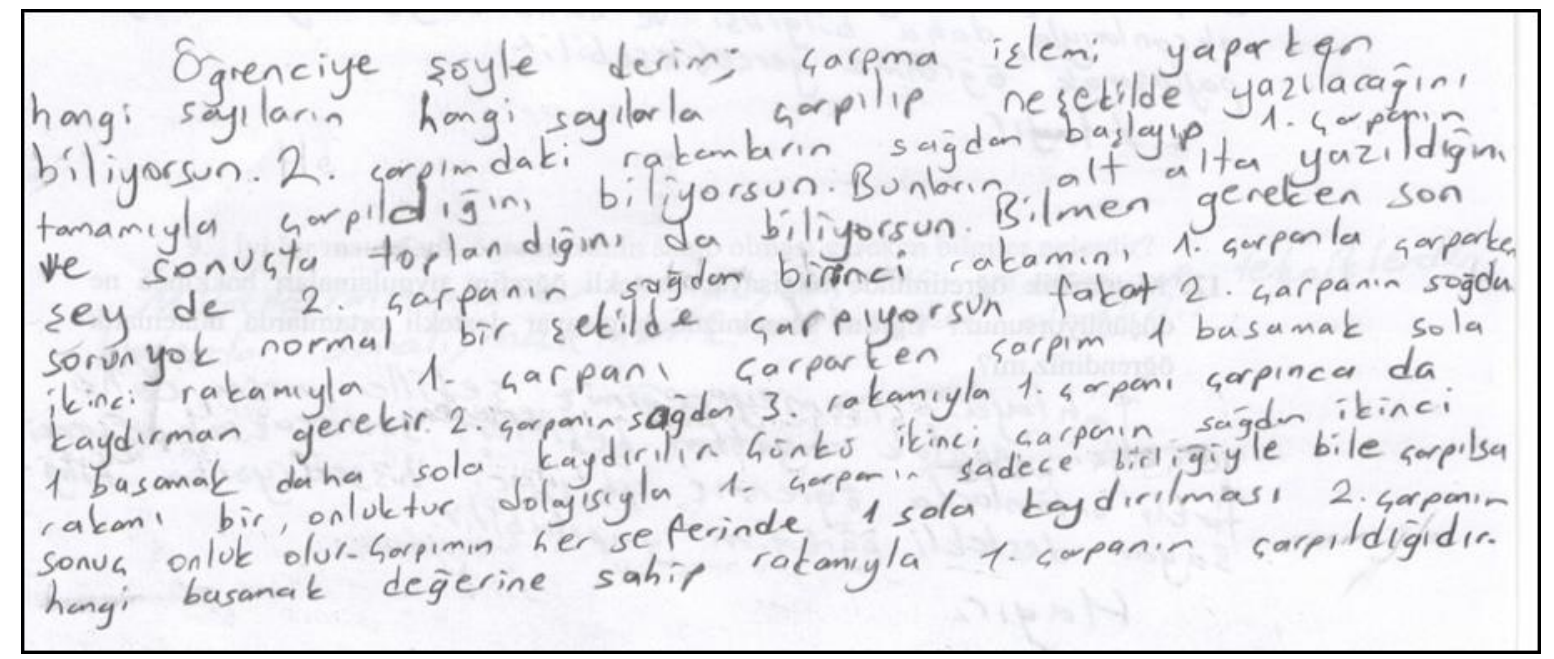

Şekil 16. A2b' nin açılaması

Senaryoda her iki uygulamada verilen cevaplar matematiği öğretme bilgisi seviyeleri açısından karşılaştırılacak olursa; ilkinde adayın basamak kaydırmaya karşı "alternatif olarak" adlandırdığı fakat yine kural odaklı bir yaklaşımla konuyu kavratmaya çalıştığı, ikincisinde ise algoritmayla ilgili daha kavramsal açıklamalar kullanarak kavramsal bilginin aktarıcısı konumunda olduğu görülmektedir. Bu iki öğretme yaklaşımında, öğretmen ve öğrencinin rolleri açısından belirgin bir farklılık olmadığı, fakat ilkinde işlemsel yollara ikincisinde ise algoritmanın arkasındaki anlama vurgu yapıldığı söylenebilir. İlk uygulamada 1 . seviyedeki adaylar, senaryonun 2.uygulamasında genellikle bu örnekteki gibi bir gelişim göstermişlerdir.

Diğer yandan 2. ve 3. uygulamalar arasında çok az sayıda adayın seviyelere bağlı olarak gelişim gösterdiği ortaya çımıştır. Bu iki uygulama arasında gelişim gösteren adaylardan biri olan A10'nun cevaplarından alınan kesitler aşağıda sunulmuştur:

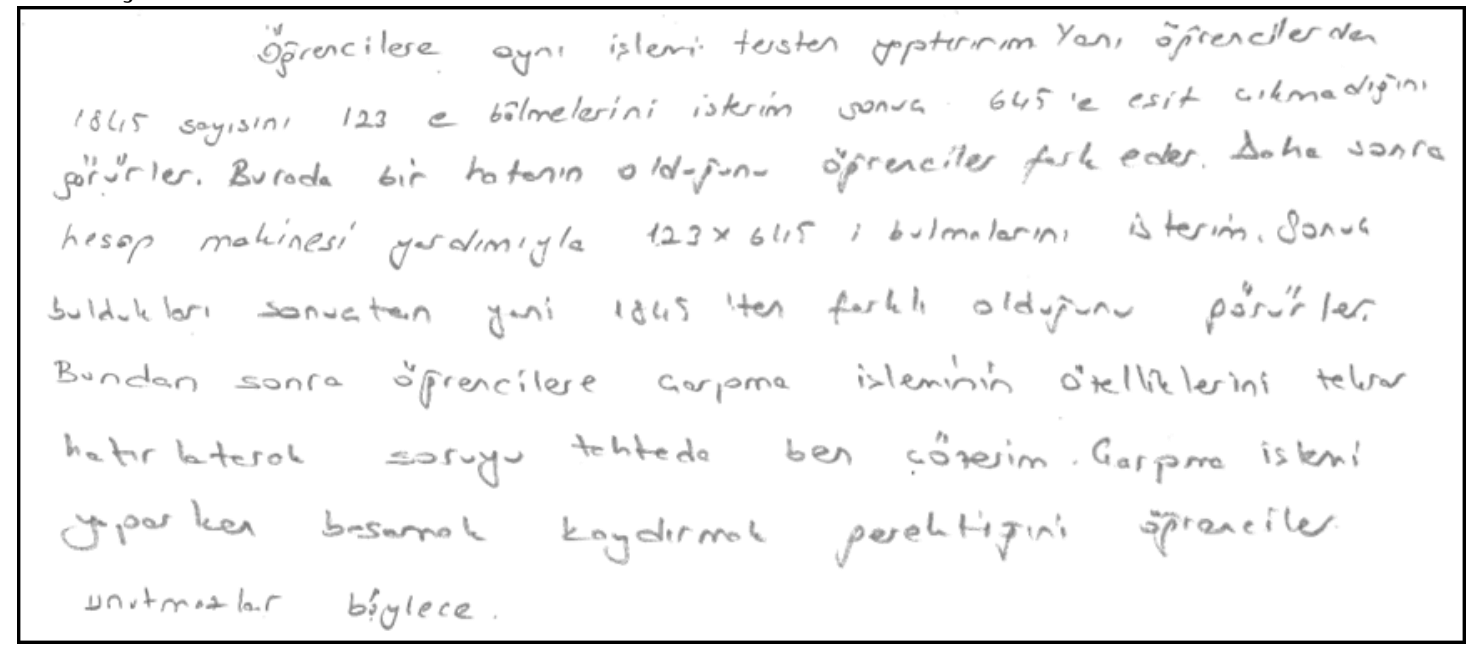

Şekil 17. A10b'nin açıklaması

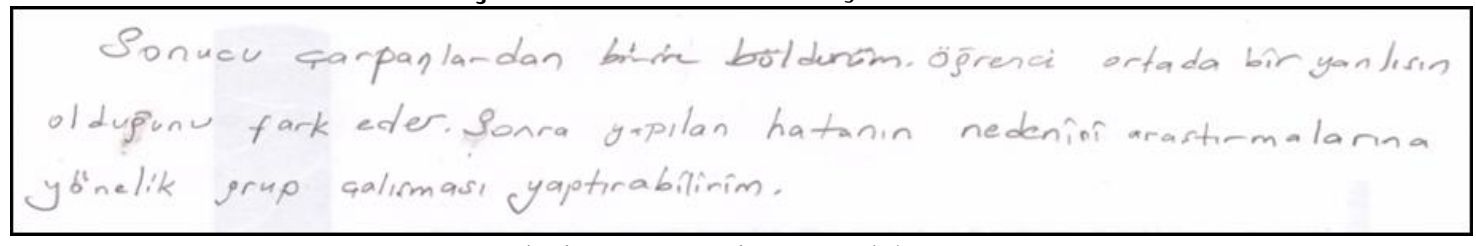

Şekil 18. A10c' nin açıklaması 
A10'nun yukarıdaki ilk cevabında, konuyu öğretme yaklaşımının ağırlıklı olarak öğretmen merkezli olduğu ve doğrudan anlatım yönteminin tercih edildiği, ikincisinde ise hatanın nedeninin araştırılmasına yönelik grup çalışması yönteminin önerildiği görülmektedir.

Çalışmaya katılan bütün öğretmen adaylarının üç farklı zamanda senaryoya verdikleri cevapların seviyelere bağlı olarak nasıl farklılaştı̆̆ını gösteren frekans/yüzde dağılımları Tablo 1'de, bu dağılımları yansıtan çizgi grafiği ise Şekil 19'da sunulmuştur:

Tablo 1

Öğretmen Adaylarının Farkh Uygulamalarda Matematiği Öğretme Bilgisi Seviyeleri

\begin{tabular}{|c|c|c|c|c|c|c|}
\hline & \multicolumn{6}{|c|}{ Seviveler } \\
\hline & \multicolumn{2}{|c|}{1} & \multicolumn{2}{|c|}{2} & \multicolumn{2}{|c|}{3} \\
\hline & $f$ & $\%$ & $f$ & $\%$ & $f$ & $\%$ \\
\hline Uygulama 1 & 11 & 31 & 19 & 54 & 3 & 9 \\
\hline Uygulama 2 & 3 & 9 & 29 & 85 & 2 & 6 \\
\hline Uygulama 3 & 1 & 3 & 26 & 79 & 6 & 18 \\
\hline
\end{tabular}

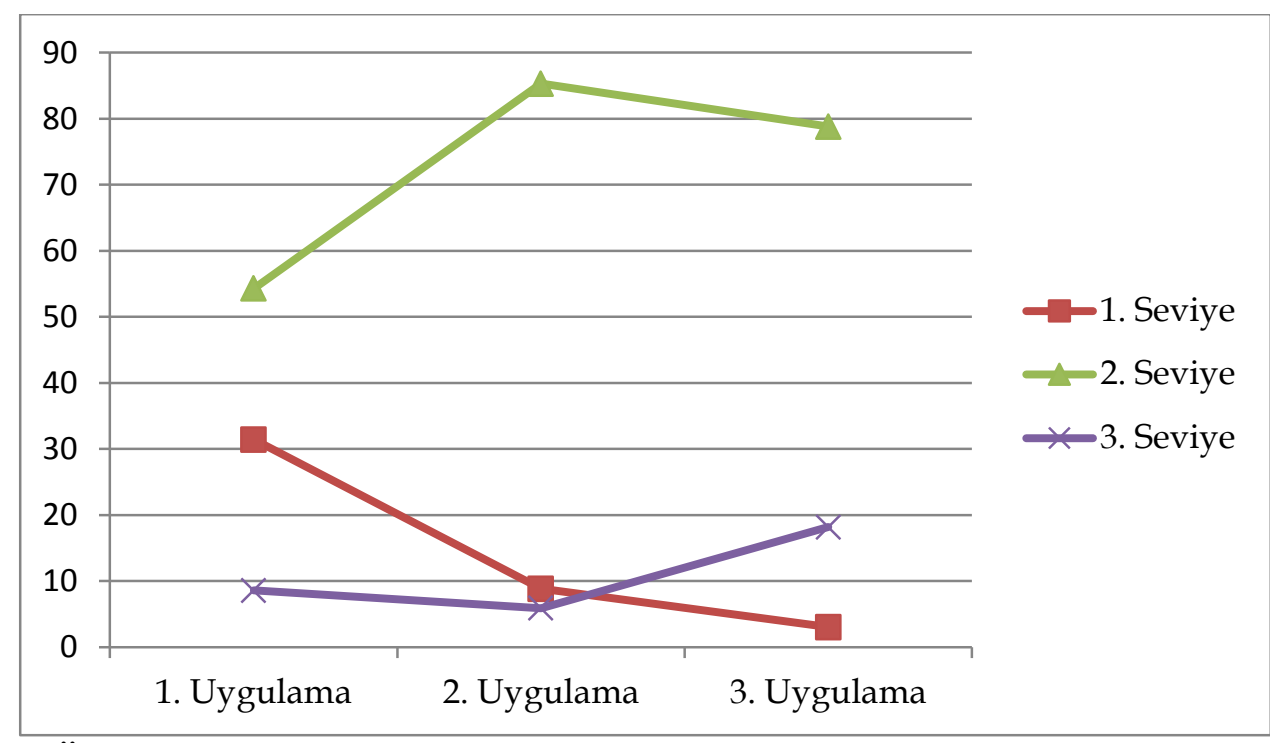

Şekil 19. Öğretmen adaylarının matematiği öğretme bilgisi seviyelerinin üç uygulamadaki yüzde dağılımlarının karşılaştırılması

Yukarıdaki grafikte, adayların senaryodaki cevaplarının her üç uygulamada da 2. seviyede yoğunlaştığı görülmektedir. Yine grafikte 1. seviyedeki adaylar göz önüne alındığında, 2. uygulamada ani bir düşüşün olduğu ve sürecin sonuna kadar bu düşüşün devam ettiği görülmektedir. 3. seviyedeki adayların ise tüm uygulamalarda az sayıda olduğu ve 3. uygulama da en fazla sayıya ulaştığı ortaya çıkmıştır. Tüm bu göstergeler, 3. uygulamadaki adayların alanı öğretme bilgilerinin nitelikleri açısından diğer uygulamalardakine nazaran daha iyi durumda olduklarını yansıtmaktadır. Ayrıca 1. seviyedeki adayların 2. uygulamadaki ani düşüşü göz önüne alındığında, yalnızca işlem yolunu göstermeye dayalı yaklaşımların yerini anlamı göstermeye dayalı yaklaşımlara bıraktığı, böylelikle bu dönem sürecinde adayların matematiği öğretme bilgilerinin niteliklerinde olumlu yönde bir değişimin olduğu söylenebilir. Özetle, tüm bu bulgular öğretmen adaylarının matematiği öğretme 
bilgilerinin niteliklerini genellikle birinci seviyeden ikinci seviyeye doğru geliştirdiklerini, bunun yanında üçüncü seviyeye doğru gelişimin yeterince gerçekleşmediğini göstermektedir.

\section{Tartışma, Sonuç ve Öneriler}

Bu çalışmada öğretmen adayları, üç basamaklı iki sayıyı çarparken çarpma çizgisinin altındaki her bir sayıyı birer sola kaydırmayı unutan ve böylece hatalı hesaplama yapan bazı öğrencilerin olduğu bir sınıfta, ne tür yaklaşımlar benimseyecekleri hususunda yorum yapmışlardır. Adayların bu özel öğretme bağlamına ilişkin yorumları; genel olarak çarpma işlemini nasıl öğretebileceklerini, betimledikleri öğrenme ortamında öğrenci ve öğretmeni nasıl konumlandırdıklarını, öğrenci zorluklarının nedenleri hakkındaki görüşlerini ve bu zorlukların üstesinden nasıl gelebilecekleriyle ilgili yaklaşımlarını yansıtmıştır.

Senaryonun ilk uygulamasında sayıları daha fazla olan 1. seviyedeki adaylar, genellikle çarpma işlemi yapmanın kurallarını öğrencilerine doğrudan aktaran konumda olmuşlardır. Bu adaylar hatanın kaynağını, öğrencilerin kavramsal eksikliklerinden ziyade, senaryoda da ifade edildiği gibi işlemsel basamakları unutmalarına bağladıkları için, açıklamalarında yalnızca kural ve işlem yollarını hatırlatmayı yeterli görmüş olabilirler. Aynı senaryonun kullanıldığı bazı çalışmalarda $\mathrm{da}$, hem aday hem de deneyimli öğretmenlerin, öğretim yaklaşımlarında kural ve işlem yollarını sözel olarak öğrenciye aktarmanın ötesinde farklı stratejiler öneremedikleri ortaya çıkmıştır (Bütün, 2005; Ma, 2010; Wiles, 2001). Senaryonun ilk uygulamasından sonra bu seviyedeki adayların öğretme bilgilerinin genellikle 2 . seviyeye doğru gelişim gösterdiği belirlenmiştir. Sayıları senaryonun her üç uygulamasında da oldukça fazla olan 2. seviyedeki adaylar, geleneksel çarpma işlemi algoritmasının ne anlama geldiğini öğrencilerine doğrudan anlatma ve gösterme çerçevesinde öğretme planları oluşturmuşlardır. Öğrencilerin hatasını, özellikle basamak değeri ile ilgili kavramsal eksikliklerine bağlayan bu adayların büyük bir çoğunluğu anlatma ve gösterme odaklı yaklaşımlarında yalnızca sözel ifadeleri kullanmışlardır. Diğerlerinin ise sözel ifadelerini desteklemek için basamak tablolarını kullanma, daha küçük sayılarda çarpma yapma, 10 ve 100 ile çarpma yapma, hatalı çarpma işleminin sonucunu çarpanlardan birine bölme ya da hesap makinesi ile sonucu kontrol etme gibi farklı yollarla konuyu kavratma girişiminde oldukları belirlenmiştir. Adayların konuyu kavratmaya yönelik uyguladıkları bu farklı tekniklerin öğrenci zorluklarının üstesinden gelinmesindeki potansiyelleri farklılaşabilmekle birlikte, tüm tekniklerde ortak olan nokta; hatayı - doğrusunu anlatarak - “düzelten", böylelikle kavramsal bilgiyi öğrencisine aktaran otorite konumunda bir öğretmenin yer almasıdır. Yani bu seviyedeki adaylar öğretmenin rolünü, farklı gösterim şekillerini öğrencilere sunma ve bu gösterimler aracılığıyla konuyu doğrudan açıklama çerçevesinde ele almışlardır. Ball'ın (1988) çalışma grubundaki öğretmen adaylarının birçoğu da, aynı senaryoya verdikleri cevaplarda matematik öğretmenine bu şekilde bir rol biçmişlerdir. Yine burada dikkat çekilmesi gereken diğer bir nokta ise, farklı teknikler/gösterim şekilleri, öğrencilerin üzerinde aktif olarak çalışıp uygun anlamları oluşturması, hatalarını düzeltmesi amacıyla kullanılmaktan ziyade, adayların kendi doğrudan anlatımlarının kolaylaştırıcıları olarak konumlandırılmıştır. Konunun öğretimine ya da yanlışın düzeltilmesine yönelik bu tekniklerin uygulanma şekilleri betimlenirken yer yer öğrencilere de rol 
biçildiği, fakat öğrenci-öğrenci etkileşimine neredeyse hiç yer verilmediği ortaya çıkmıştır. Yani yapılan yorumlarda, hata yapan öğrenci/öğrencilerin birbirleri arasında ve sınıfın geri kalanı ile etkileşime girebilecekleri biçimde bir öğretme planı çizilmemiştir. Confrey (1990), öğrencilerin kavram yanılgılarının “doğrudan öğretime" karşı dirençli olduğunu, bu yüzden öğrencilerin daha aktif olarak konumlandırıldığı, öğrenci-öğrenci etkileşiminin ön planda olduğu alternatif öğretim yaklaşımlarının geliştirilmesi gerektiğini ifade etmektedir. Senaryonun farklı uygulamalarında, sözü edilen bu alternatif öğretim yaklaşımlarının karakterize edildiği 3. seviyede çok az adayın yer aldığı ve adayların bu yönde belirgin bir gelişim göstermedikleri ortaya çıkmıştır. Bu seviyedeki adaylar, 2. seviyedekilerden farklı olarak, konuyu öğretirken öğrencilerini çarpma işleminin arkasındaki anlama doğru yönlendirebileceklerini (örn. grup çalışmaları aracılığıyla) ve öğrencilerin hatanın nedenleri üzerine düşünmelerine fırsat vererek, bu hatayı kendilerinin düzeltmesini sağlayabileceklerini ifade etmişlerdir. 10x10 işlemini öğrencilerine sunarak basamak kaydırmayı doğrudan açıklayan ya da bu şekilde hatayı "düzelten" 2. seviyedeki bir öğretmenle, aynı işlemi grup çalışması yöntemiyle öğrencilerinin yorumuna açan ve böylelikle hatalarını kendilerinin fark etmelerine ve düzeltmelerine fırsat veren bir öğretmen arasında öğretme bilgisi açısından niteliksel bir farklılık bulunmaktadır. Borasi (1994) öğrencilerin hatalar üzerinde sistemli bir şekilde düşünmeleri sağlanarak, bu hataların öğretimde birer sıçrama noktası (springboard) olarak kullanılabileceğini ifade etmektedir. Hataları öğrencinin öğrenmesi açısından bir avantaja çevirme, üst düzey öğretme bilgisinin bir göstergesidir. Çalışmanın sonuçları, lisans eğitimi sürecindeki bir yıllık zaman diliminde bu nitelikte bir bilgiye ulaşmanın çok da kolay olmadığını ortaya çıkarmıştır. Bu sonuç aynı zamanda, adayların Özel Öğretim Yöntemleri I-II derslerindeki kazanımlarının 1.seviyeden 2. seviyeye geçişi sağlamada yardımcı olduğunu, fakat 3. seviyeye doğru gelişimi yeterince desteklemediğini söylemektedir.

Tüm bu sonuçlar, adayların lisans eğitimleri sürecinde matematiği öğretme bilgilerini geliştirmenin öğretmen eğitimcileri için ne kadar zorlu bir görev olduğunu tekrar ortaya çıkarmıştır. Ülkemizde matematik öğretimi işlemsel görüşe dayandığı için, fakültelere gelen birçok aday matematiğin kural, formül ve işlem yığınından oluşan bir konu alanı olduğu, matematik öğrenmenin daha çok ezberleme ve tekrarlama yoluyla gerçekleştiği, bağlantılı olarak matematiği öğretmenin de öğrenciye bu anlamsız ve bağlantısız bilgi parçacıklarının aktarılması yoluyla gerçekleşebileceği inancındadır (Baki, 2008). Bu tür algılar çok uzun bir sürede yapılandırıldığından, fakülte sürecinde değiştirilmesinin oldukça zor olduğu ifade edilmektedir (Oliveira ve Hannula, 2008; Schoenfeld ve Kilpatrick, 2008). Öğretmen eğitimcileri olarak, matematiği öğretme bilgisinin niteliğinin artırılmasına yönelik etkili programlar/uygulamalar geliştirmek istiyorsak, başlangıçta bu kökleşmiş algıların farkında olmalı ve öğretmenlerin/öğretmen adaylarının birçoğu örtük olan bu algılarını açık hale getirecekleri ve bunların üzerinde düşünüp sorgulayabilecekleri öğrenme ortamları oluşturmalıyız. Bu ortamlarda, özellikle geçmişte kural odaklı öğrenilen temel konu ve kavramlara odaklanarak, öğretmenlerin/öğretmen adaylarının bunları öğrenci rolünde, yeni bir bakış açısıyla tekrar öğrenmelerini sağlamalıyız. Lisans eğitimi sürecindeki alan eğitimi dersleri bu tür ortamların oluşturulması için en uygun bağlam olarak değerlendirilebilir. Çalışmanın sonuçları 
1şığında, bu derslerde kuramdan ziyade uygulama boyutuna daha fazla ağırlık verilmesi gerektiği önerilebilir. Bu çalışmada Özel Öğretim Yöntemleri II dersindeki mikro-öğretim çalışmalarında adaylar her ne kadar farklı öğretim yöntemlerini uygulamaya koymak için fırsat bulmuş olsalar da, senaryodaki yorumlarına yansıtacak kadar bu yöntemleri özümseyemedikleri ortaya çıkmıştır. Özel Öğretim Yöntemleri II dersindeki mikro-öğretim çalışmalarında, kural odaklı öğretime daha yatkın olan özel konular belirlenerek, adaylardan bu konularda planlar hazırlamaları ve ders işlemeleri istenebilir. Böylece adaylar, doğrudan anlatma ve göstermenin ötesindeki farklı yöntemleri bu konularda işe koşarak, sözü edilen özümseme süreçlerini kolaylaştırabilirler. Gelecekte yapılacak araştırmalarda, mesleğe yeni başlayan öğretmenlerin matematiği öğretme bilgileri, gerçek sinıflardaki uygulamaları mercek altına alınarak incelenebilir. Böylece lisans eğitimi sürecinin matematiği öğretme bilgisi üzerindeki etkileri farklı kavram ve konularda, daha kapsamlı ve gerçekçi bir şekilde ortaya konulabilir.

\section{Kaynakça}

Baki, A. (2008). Kuramdan uygulamaya matematik eğitimi. Ankara: Harf Eğitim Yayınları.

Baki, A. (2010). Öğretmen eğitiminin lisans ve lisansüstü boyutlardan değerlendirilmesi. İnönü Üniversitesi Ĕ̆itim Fakültesi Dergisi, 11(3), 15-31.

Ball, D., L. (1988). Knowledge and reasoning in mathematical pedagogy: examining what prospective teachers bring to teacher education (Yayınlanmamış doktora tezi). Michigan State University, Michigan.

Borasi, R. (1994). Capitalizing on errors as "Springboards for inquiry: a teaching experiment. Journal for Research in Mathematics Education, 25(2), 166-208. https://doi.org/10.2307/749507

Bütün, M. (2005). İlköğretim matematik öğretmenlerinin alan eğitimi bilgilerinin nitelikleri üzerine bir çalışma (Yüksek Lisans Tezi). Karadeniz Teknik Üniversitesi, Fen Bilimleri Enstitüsü, Trabzon.

Bütün, M. (2011). Matematik Öğretmenlerinin alan eğitimi bilgi yapılarının incelenmesinde senaryo tipi mülakat sorularının kullanımı. Dicle Üniversitesi Ziya Gökalp Ĕ̈itim Fakültesi Dergisi, 16, 105-115.

Confrey, J. (1990). What Constructivism Implies for Teaching. In R. B. Davis, C. A., Maher and N. Noddings (Eds.), Constructivist views on the teaching and learning of mathematics (pp.107-122). Reston, Virginia: The National Council of Teachers of Mathematics.

Çepni, S. (2012). Araştırma ve proje çalışmalarına giriş. Trabzon: Celepler Matbaa.

Ernest, P. (1989). The Impact of Beliefs on the Teaching of Mathematics, In Ernest. P. (Ed.), Mathematics Teaching: The State of the Art (pp.249-254). New York: The Falmer Press.

Fenemma, E. and Franke, M., L. (1992). Teachers' Knowledge and its impact. In Dauglas A. Grouws (Ed.), Handbook of research on mathematics teaching and learning (pp. 147-164). New York: Macmillan.

Gökkurt, B., Şahin, Ö., Soylu, Y., ve Doğan, Y. (2015). Öğretmen adaylarının geometrik cisimler konusuna ilişkin öğrenci hatalarına yönelik pedagojik alan bilgileri. İlköğretim Online, 14(1).

Graeber, A., ve Tirosh, D. (2008). Pedagogical Content Knowledge, In P. Sullivan and 
T. Wood (Eds.), Knowledge and beliefs in mathematics teaching and teaching development, (pp.117-132). Rotterdam: Sense Publishers.

Koç Başaran, Y. (2017). Sosyal bilimlerde örnekleme kuramı, Akademik Sosyal Araştırmalar Dergisi, 5(47), 480-495.

Lampert, M. (1986). Knowing, doing, and teaching multiplication. Cognition and Instruction, 3(4), 305-342. https://doi.org/10.1207/s1532690xci0304_1

Leung, F. ve Park, K. (2002). Competent students, competent teachers? International Journal of Educational Research, 37(2), 113-129. https:/ / doi.org/10.1016/S08830355(02)00055-1

Ma, L. (1999). knowing and teaching elementary mathematics: Teachers' understanding of fundamental mathematics in China and the United States. Mahwah, NJ, Lawrence Erlbaum.

Oliveira, H. and Hannula, M., S. (2008). Individual prospective mathematics teachers: studies on their professional growth. In K. Krainer and T. Wood (Eds.), Participants in mathematics teacher education (pp. 13-34). Rotterdam: Sense Publishers.

Ponte, J., P. ve Chapman, O. (2008). Preservice mathematics teachers' knowledge and development. In L. English (Ed.), Handbook of international research in mathematics education (pp.225-263). New York, NY: Routledge.

Schoenfeld, A., H. ve Kilpatrick, J. (2008). Toward a theory of proficiency in teaching mathematics. In D. Tirosh and T. Wood (Eds.), International handbook of mathematics teacher education, Volume 2: Tools and processes in mathematics teacher education (pp. 321-354). Rotterdam, Netherlands: Sense Publishers.

Shulman, L., S. (1986). Those who understand: knowledge growth in teaching. Educational Researcher, 15(2), 4-14. https:/ / doi.org/10.3102/0013189X015002004

Shulman, L., S. (1987). Knowledge and teaching: foundations of the new reform. Harvard Educational Review, 57(1) 1-22. https:/ / doi.org/10.17763/haer.57.1.j463w79r56455411

Sugiyama, Y. (2008). Introduction to elementary mathematics education, Tokyo: Toyokan.

Takahashi, A. (2010, March). Prospective and practicing teacher professional development with standards. In APEC Conference on Replicating Exemplary Practices in Mathematics Education, Koh Samui, Thailand, (pp. 8-12).

Thompson, A., G. (1991). The Development of teachers' conceptions of mathematics teaching. Proceedings of the Thirteenth Annual Meeting of the North American Chapter of the International Group for the Psychology of Mathematics Education, Virginia, USA.

Türnüklü, E. B. (2005). Matematik öğretmen adaylarının pedagojik alan bilgileri ile matematiksel alan bilgileri arasındaki ilişki. Eurasian Journal of Educational Research (EJER), (21).

Wiles, P., S. (2001). Coordinating mathematical and pedagogical. content in preservice teacher education (Yayınlanmamiş doktora tezi). University of WisconsinMadison.

Yeşildere, S. ve Akkoç, H. (2010). Matematik öğretmen adaylarının sayı örüntülerine ilişkin pedagojik alan bilgilerinin konuya özel stratejiler bağlamında incelenmesi. Ondokuz Mayıs Üniversitesi Eğitim Fakültesi Dergisi, 29(1), 125-149. 
YÖK (1998). Ĕ̆itim fakülteleri öğretmen yetiştirme programlarının yeniden düzenlenmesi, Ankara.

YÖK (2006). Eğitim fakültesi öğretmen yetiştirme lisans programları. Ankara: Haziran.

YÖK (2007). Öğretmen yetiştirme ve eğitim fakülteleri (1982-2007). Ankara: Yükseköğretim.

YÖK, 2008. Yeni öğretmen yetiştirme lisans programları. http://www.yok.gov.tr/web/guest/icerik//journal_content/56_INSTANCE rEHF8BIsfYRx/10279/41807946 adresinden alınmıştır.

\section{Summary}

\section{Introduction}

One of the main problems of teacher education research from past to present is how and in what context can teachers gain their knowledge and skills in the undergraduate education process. Many studies emphasized that pre-service teachers are not profound enough to teach the field in various subjects and concepts within the context of school mathematics (pedagogical content knowledge) and that different course designs should be developed and implemented in order to enrich this knowledge during the undergraduate education process. In addition, these researches suggest that pre-service teachers should be examined at specific time intervals and at the end of the process in order to better understand and determine the characteristics of effective curriculum design or curriculums in the development of pedagogical content knowledge structures.

Numerous studies have been carried out to examine the characteristics of mathematics teachers' pedagogical content knowledge in different subjects and concepts in Turkey (Türnüklü, 2005; Yeşildere and Akkoç, 2010; Gökkurt et. al., 2015). Many of these studies have identified the situation and do not fully reflect the development of the knowledge in the undergraduate education process. The theoretical framework for pedagogical content knowledge suggests that it takes a long time to formulate this knowledge, and that the development of pre-service teachers should be followed at length during the undergraduate education period (Ponte and Chapman, 2008). In this study, the development of pedagogical content knowledge of the pre-service teachers who took the Special Teaching Methods I-II courses in the Elementary Mathematics Teaching Curriculum was examined. This study was carried out for the multiplication of natural numbers, which is one of the basic subjects of school mathematics.

\section{Method}

In this study, longitudinal developmental research method, which is one of the descriptive research methods, was used (Çepni, 2012). In the elementary mathematics teacher education program, it was tried to determine the structure of the pedagogical content knowledge in the process by studying longitudinally with the third grade preservice teachers. The participants of the study consisted of 35 pre-service teachers in the 3rd grade who study in the elementary mathematics teaching department of an education faculty in the Black Sea region. In order to examine the development of pedagogical content knowledge of pre-service teachers, a teaching scenario supported by open-ended questions was prepared. In this scenario, pre-service teachers were 
asked to interpret the error students had made while multiplying two three-digit numbers and to create a teaching plan to overcome this error. The data of the study were analyzed descriptively by the three levels of pedagogical content knowledge related to the teaching scenario, so that both the process and the periodic developments of the pre-service teachers were tried to be revealed.

\section{Results}

The pre-service teachers, whose answers were classified at level 1, tended to explain the rules to the student/students directly about how the algorithm in the multiplication process works. They do not mention the meaning under the rules in the teaching approaches they propose and explain. They gave the teacher the role of rules and the ways of processing. In the second level, the pre-service teachers stated that they can directly show and explain to the student what the algorithm means and why the algorithm is explained in that way. They have positioned their roles in teaching approaches as explanatory and authority of knowledge. They have stated that there may be conceptual reasons of the mistakes made by the students, but they attempted to correct them by telling the truth but by emphasizing the meaning. On the other hand, pre-service teachers at level 3 did not position themselves as directly explaining the subject in the instructional approaches, they defined and stated that they could direct the student/ students behind the multiplication process.

It has been found out that the answers of the pre-service teachers in the scenario are concentrated in the 2 nd level in all three applications. It was found that the 3rd level pre-service teachers are less than others in all applications and reached the highest number in the 3rd application. All these indicators reflect that the preservice teachers in the 3rd application are better in terms of the qualifications of pedagogical content knowledge than first two applications. Moreover, considering the sudden drop in the 2nd application of pre-service teachers at the 1st level, only the approaches based on the process were replaced by approaches based on showing meaning. Thus, it can be said that there is a meaningful change in the characteristics of the pedagogical content knowledge in this period. In summary, all these findings show that the pre-service teachers generally develop the characteristics of this knowledge from the first level to the second level, and that the development towards the third level is not enough.

\section{Discussion and Conclusion}

The findings of the study have again revealed how challenging it is for teacher educators to develop pedagogical content knowledge in the process of undergraduate education. In our country, mathematics teaching is based on procedural view. For this reason, many pre-service teachers who come to faculties think that mathematics is a subject area consisting of rules, formulas and processes, and that mathematics learning is mostly through memorization and repetition. In addition, they believe that mathematics can be realized by transferring these meaningless and unconnected pieces of information to the student (Baki, 2008). As teacher educators, if we are to develop effective programs / practices to increase the quality of teaching mathematics, we must initially be aware of these deep-rooted beliefs, and we need to create learning environments where teachers / pre-service teachers will be able to clarify and conceal these perceptions that are implicit. In these environments, we should focus on the 
fundamental topics and concepts learned in the past, especially in the context of the rule-oriented, so that teachers / pre-service teachers can learn from a new perspective in their student role. Mathematics teaching courses in the pre-service teacher education process can be considered as the most appropriate context for the creation of such environments. In the light of the findings obtained from the study, it may be suggested that more emphasis should be given to the application dimension than to the theory. In this study, although it was found that pre-service teachers had the opportunity to put into practice different teaching methods in micro teaching studies in Special Teaching Methods II course, they could not assimilate these methods enough to reflect their comments in the scenario. Thus, pre-service teachers can facilitate the assimilation processes mentioned above by working on different methods beyond direct expression and demonstration. In the future researches, the teaching of mathematics teachers who are new to the profession can be examined by examining the applications in real classes. Thus, the effects of the undergraduate education process on their pedagogical content knowledge can be revealed in a more comprehensive and realistic way on different subjects.

\section{Authors' Biodata / Yazar Bilgileri}

Mesut BÜTÜN Cumhuriyet Üniversitesi Eğitim Fakültesi'nde doktor öğretim üyesi olarak görev yapmaktadır. Doktorasını Karadeniz Teknik Üniversitesi Eğitim Bilimleri Enstitüsü'nde tamamlamıştır. İlgi duyduğu çalışma konuları öğretmen eğitimi, alanı öğretme bilgisi ve ders imecesidir.

Mesut Bütün is an assistant professor in Education Faculty of Cumhuriyet University, Sivas, Turkey. He completed his doctoral degree at the Educational Sciences Institute of Karadeniz Technical University, Turkey. His research interests include mathematics teacher education and lesson study.

Adnan BAKİ Trabzon Üniversitesi Eğitim Fakültesi'nde profesör olarak görev yapmaktadır. Doktorasını Londra Üniversitesi Eğitim Bilimleri Enstitüsü'nde tamamlamıştır. İlgi duyduğu çalışma konuları öğretmen eğitimi ve öğretmen gelişimidir.

Adnan Baki is a professor in Education Faculty of Trabzon University, Trabzon, Turkey. He completed his doctoral degree at the University of London-Institute of Education. His research interests include mathematics teacher education and teacher development. 